\section{OAK RIDGE NATIONAL LABORATORY}

MARTIN MARIETRA

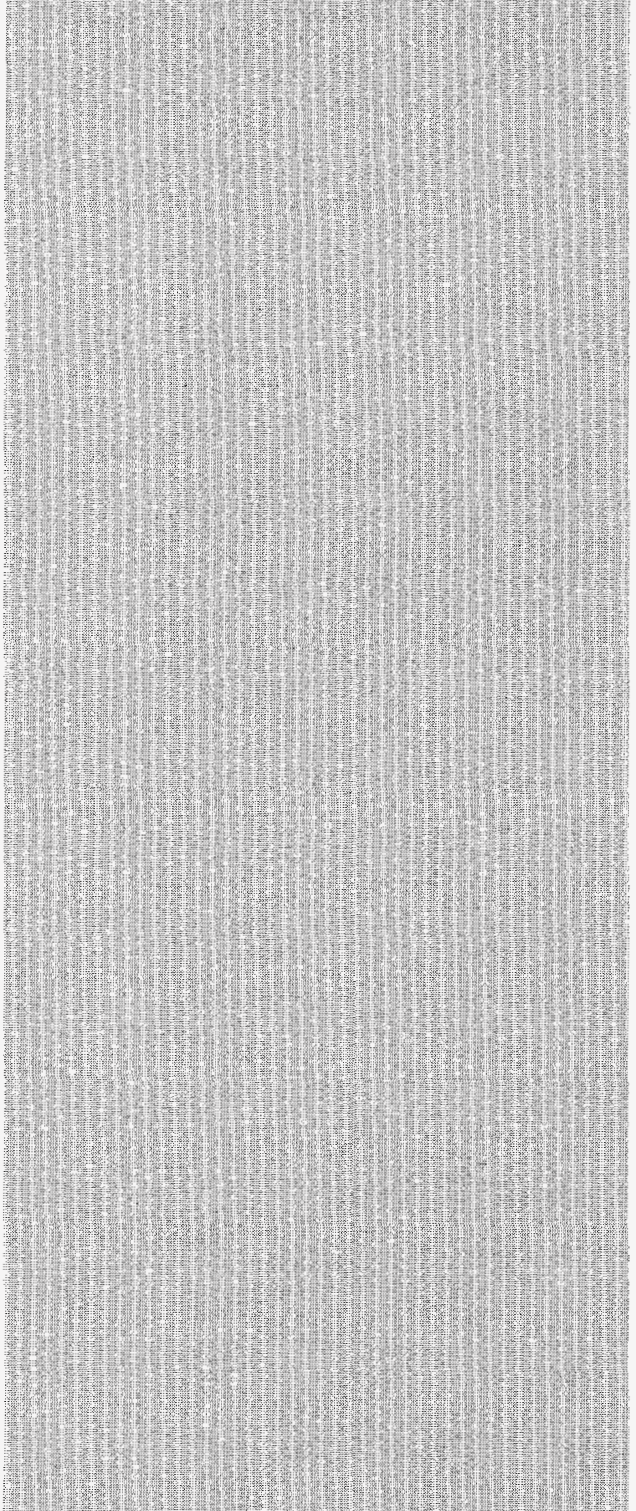

MANAGED BY

MARTIN MARIETTA ENERGY SYSTEMS, INC. FOR THE UNITEO STATES DEPARTMENT OF ENEPGY

\section{Reference Values for Total Blood Volume and Cardiac Output in Humans}

Lynn R. Williams ham $-3, y=b$

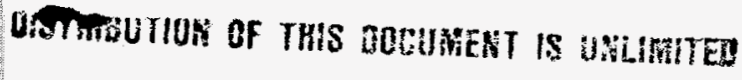

OCT 121994 
This report has been reproduced directly from the best available copy.

Available to DOE and DOE contractors from the Office of Scientific and Technical Information, P.O. Box 62, Oak Ridge, TN 37831 ; prices available from (615) 576-8401, FTS 626-8401.

Available to the public from the National Technical Information Service, U.S. Department of Commerce, 5285 Port Royal Rd., Springfield, VA 22161.

This report was prepared as an account of work sponsored by an agency of the United States Government. Neither the United States Government nor any agency thereof, nor any of their employees, makes any warranty, express or implied, or assumes any legal liability or responsibility for the accuracy, completeness, or usefulness of any information, apparatus, product, or process disclosed, or represents that its use would not infringe privately owned rights. Reference herein to any specific commercial product, process, or service by trade name, trademark, manufacturer, or otherwise, does not necessarily constitute or imply its endorsement, recommendation, or favoring by the United States Government or any agency thereof. The views and opinions of authors expressed herein do not necessarily state or reflect those of the United States Government or any agency thereof. 


\section{DISCLAIMER}

\section{Portions of this document may be illegible in electronic image products. Images are produced from the best available original document.}




\title{
REFERENCE VALUES FOR TOTAL BLOOD VOLUME AND CARDIAC OUTPUT IN HUMANS*
}

\author{
Lynn R. Williams \\ Associate Dean and Professor of Mathematics \\ Division of Liberal Arts and Sciences \\ Indiana University South Bend \\ PO Box 7111 \\ South Bend, IN 46634 \\ Work performed for the \\ Dosimetry Research Group \\ Health Sciences Research Division \\ Oak Ridge National Laboratory \\ Oak Ridge, Tennessee 37831
}

September 1994

*Research sponsored by the Office of Health and Environmental Research, U. S. Department of Energy under contract DE-AC05-840R21400 with Martin Marietta Energy Systems, Inc. 


\section{INTRODUCTION}

Much research has been devoted to measurement of total blood volume (TBV) and cardiac output $(\mathrm{CO})$ in humans but not enough effort has been devoted to collection and reduction of results for the purpose of deriving typical or "reference" values. Identification of normal values for TBV and $\mathrm{CO}$ is needed not only for clinical evaluations but also for the development of biokinetic models for ultra-short-lived radionuclides used in nuclear medicine (Leggett and Williams 1989).

The purpose of this report is to offer reference values for TBV and CO, along with estimates of the associated uncertainties that arise from intra- and inter-subject variation, errors in measurement techniques, and other sources. Reference values are derived for basal supine $\mathrm{CO}$ and TBV in reference adult humans, and differences associated with age, sex, body size, body position, exercise, and other circumstances are discussed. 


\section{TOTAL BLOOD VOLUME}

The analysis of TBV is based on the results of 18 original studies involving 1160 subjects (Allen et al. 1956, Berlin et al. 1951, Brady et al. 1953, Bratteby 1968, Brines et al. 1941, Brody and Nilsson 1960, Brown et al. 1962, Chien et al. 1966, Cohn and Shock 1949, Gibson and Evans 1937, Gibson et al. 1946, Moore et al. 1963, Morse et al. 1947, Nomof et al. 1954, Retzlaff et al. 1969, Schmidt et al. 1956, von Porat 1951, Wennesland et al. 1959). Measurements of TBV are based on a variety of different methods which generally require separate estimates of circulating plasma volume and the volume of the cells in the vascular space. In some studies, separate measurements of circulating plasma volume and red cell volume have been made in each subject, but more often only one of these was measured and the other was inferred using a measurement of venous hematocrit. Plasma volume studies typically use dye dilution methods or radionuclide labelling and red cell volume studies use radionuclide labelling.

There are two potential sources of error when the venous hematocrit is used to estimate TBV: (1) the measured venous hematocrit generally overestimates actual venous hematocrit due to the less than perfect packing of cells by the centrifuge and (2) the venous hematocrit is larger than the whole body hematocrit. Variation in technique can lead to different fractions of plasma trapped in the red cell column of centrifuged blood (reported range 2-8\% in Chaplin and Mollison 1952), but several investigators (Brady et al. 1953, Chien et al. 1966, Cohn and Shock 1949, Nadler and Hidalgo 1965, Schmidt et al. 1956) multiplied measured hematocrit by 0.96 to obtain a corrected hematocrit. Over a wide range of body hematocrit the average ratio of whole body hematocrit to corrected venous hematocrit is nearly constant with a value of 0.91 in normal humans (reported range 0.87-0.92, Chaplin et al. 1953, Nadler and Hidalgo 1965, Retzlaff et al. 1969). In this review, these same correction factors ( 0.96 and 0.91 ) were applied to adjust published TBV values from studies not using correction factors. Studies of TBV not using correction factors and not reporting individual hematocrit values were not used in the analysis of TBV.

Data on TBV are summarized in Table 1 and suggested reference TBV values for a given age are presented in Table 2. Trimmed means were computed by dropping the highest $20 \%$ and the lowest $20 \%$ of study values in each age range and computing a mean for the remaining middle $60 \%$ of the study values. Most measurements of human TBV have been on young adults, usually males. Two studies (Brines et al. 1941, Morse et al. 1947) were conducted on infants and children, and two 
Table 1. Summary of reported values of blood volume within age groups.

\begin{tabular}{|c|c|c|c|c|c|c|c|c|}
\hline \multicolumn{9}{|c|}{ Blood Volume (L) } \\
\hline \multirow[b]{2}{*}{$\begin{array}{c}\text { Age range } \\
(y)\end{array}$} & \multicolumn{4}{|r|}{ Males } & \multicolumn{4}{|r|}{ Females } \\
\hline & mean & s.d. & number & $\begin{array}{r}\text { trimmed } \\
\text { mean }\end{array}$ & mean & s.d. & number & $\begin{array}{r}\text { trimmed } \\
\text { mean }\end{array}$ \\
\hline $0.00-0.05$ & $0.27 *$ & 0.1 & 45 & $0.27 *$ & $0.27 *$ & 0.1 & 41 & $0.27 *$ \\
\hline $0.4-0.8$ & 0.45 & 0.1 & 5 & 0.41 & & & & \\
\hline $1.1-2.2$ & 0.88 & 0.1 & 3 & & 0.69 & 0.1 & 3 & \\
\hline $2.8-4.9$ & 1.23 & 0.2 & 3 & & 1.01 & 0.2 & 9 & 1.01 \\
\hline $5.0-7.1$ & 1.56 & 0.4 & 6 & 1.47 & 1.44 & 0.3 & 2 & \\
\hline $7.5-9.9$ & 2.11 & 0.4 & 11 & 2.06 & 1.80 & 0.4 & 7 & 1.75 \\
\hline $10-12$ & 2.66 & 0.5 & 16 & 2.67 & 2.10 & 0.4 & 7 & 2.13 \\
\hline $13-15$ & 4.34 & 1.0 & 34 & 3.95 & 3.28 & 0.5 & 7 & 3.28 \\
\hline $16-19$ & 5.03 & 0.9 & 28 & 5.05 & 3.43 & 0.5 & 11 & 3.39 \\
\hline $20-29$ & 5.28 & 0.8 & 303 & 5.24 & 3.88 & 0.6 & 137 & 3.88 \\
\hline $30-39$ & 5.12 & 0.7 & 143 & 5.09 & 4.09 & 0.6 & 62 & 4.05 \\
\hline $40-49$ & 5.34 & 0.8 & 69 & 5.30 & 3.86 & 0.6 & 27 & 3.81 \\
\hline $50-59$ & 5.06 & 0.9 & 28 & 5.03 & 3.76 & 0.7 & 20 & 3.66 \\
\hline $60-69$ & 4.92 & 0.8 & 30 & 4.83 & 3.81 & 0.8 & 6 & 3.68 \\
\hline $70-79$ & 4.62 & 0.7 & 52 & 4.57 & 3.63 & 0.7 & 43 & 3.50 \\
\hline $80-83$ & 4.39 & 0.5 & 24 & 4.36 & 3.48 & 0.6 & 17 & 3.52 \\
\hline
\end{tabular}

*Values for males and females were combined in this age group. 
4

Table 2. Suggested reference values for blood volume.

\begin{tabular}{|c|c|c|c|c|}
\hline \multirow{3}{*}{$\begin{array}{r}\text { Age } \\
(\mathrm{y}) \\
\end{array}$} & \multicolumn{4}{|c|}{ Blood Volume (L) } \\
\hline & \multicolumn{2}{|c|}{ Males } & \multicolumn{2}{|c|}{ Females } \\
\hline & mean & s. d. & mean & s. d. \\
\hline 0 & 0.27 & 0.1 & 0.27 & 0.1 \\
\hline 0.5 & 0.4 & 0.1 & 0.4 & 0.1 \\
\hline 2 & 0.8 & 0.2 & 0.7 & 0.2 \\
\hline 5 & 1.4 & 0.3 & 1.2 & 0.3 \\
\hline 10 & 2.4 & 0.5 & 2.0 & 0.4 \\
\hline 15 & 4.5 & 1.0 & 3.3 & 0.5 \\
\hline 24 & 5.3 & 0.9 & 3.9 & 0.6 \\
\hline 34 & 5.3 & 0.9 & 4.0 & 0.6 \\
\hline 44 & 5.3 & 0.9 & 3.9 & 0.6 \\
\hline 54 & 5.1 & 0.9 & 3.8 & 0.7 \\
\hline 64 & 4.8 & 0.8 & 3.7 & 0.7 \\
\hline 74 & 4.6 & 0.8 & 3.5 & 0.7 \\
\hline
\end{tabular}


studies (Bratteby 1968, Brody and Nilsson 1960) used newborns. Blood volume measurements are typically made with the subject in the recumbent position and there is a slight decrease in circulating plasma volume, and hence TBV, when the subject moves from the horizontal to the upright position (Hagan et al. 1978, Lehtovirta et al. 1972). Values in Tables 1 and 2 represent recumbent TBV.

Various authors (Allen et al. 1956, Bratteby 1968, Brown et al. 1962, Chien et al. 1966, Cropp 1971, Inkley et al. 1955, Morse et al. 1947, Retzlaff et al. 1969, Strandell 1964, von Porat 1951, Wennesland et al. 1959) have used multi-linear regression to investigate the relationships between TBV and one or more functions of height, weight, age, or body surface area (BSA), but these regressions were based on relatively small data sets. Analyses of the combined data were performed separately for males and females except newborns, for which sex generally was not reported. The data for males and females were separated into additional categories based on the age and weight of the subject: females under $40 \mathrm{~kg}$ and $13 \mathrm{y}$, males under $45 \mathrm{~kg}$ and $14 \mathrm{y}$, females over $40 \mathrm{~kg}$ and 13 $\mathrm{y}$, and males over $45 \mathrm{~kg}$ and $14 \mathrm{y}$. There are several reasons for looking at subsets of the data: (1) the relationships between TBV and age or weight appear linear but the slopes seem to be different for children than for adults; (2) the relationship between TBV and age in children is different from the relationship in adults; and (3) there are fewer data points and there is less variation in TBV in the lower weight and age groups. The data are insufficient to draw meaningful conclusions for adult females whose weight lies outside the $40-80 \mathrm{~kg}$ range or adult males whose weight lies outside the $45-100 \mathrm{~kg}$ range.

Reference TBVs for young children of a given sex, weight, and age can be obtained from one of the least squares regressions given below. In each category, an attempt was made to determine the regression variables with nonzero coefficients ( $p$ value $<0.01$ ) which appeared to satisfy the regression assumptions and yielded the equation with the highest correlation coefficient. For newborns (41 subjects), the linear least squares regression of TBV on weight yields

$\operatorname{TBV}(\mathrm{L})=0.0875 \times$ weight $(\mathrm{kg})$

with $r^{2}=0.98$. For female children ( 30 subjects aged $1 \mathrm{w}$ to $12.5 \mathrm{y}$ ), the multiple linear regression of TBV on weight and age yields

$$
\text { TBV }(\mathrm{L})=0.2263+0.0326 \times \text { weight }(\mathrm{kg})+0.0784 \times \text { age }(\mathrm{y})
$$

with $r^{2}=0.90$. The corresponding multiple linear regression equation for male children ( 57 subjects aged $3 \mathrm{w}$ to $13.9 \mathrm{y}$ ) is

$\operatorname{TBV}(\mathrm{L})=0.0393 \times$ weight $(\mathrm{kg})+0.1299 \times$ age $(\mathrm{y})$

with $r^{2}=0.98$. 
Height has been used as a predictor variable in several published regression equations involving TBV (Brown et al. 1962, Chien et al. 1966, Morse et al. 1947, Retzlaff et al. 1969, Strandell 1964, von Porat 1951, Wennesland et al. 1959). Weight and the cube of height, used as dependent variables (Allen et al. 1956) to predict TBV in adults, seem to yield better regression equations of TBV than linear equations using combinations of weight, age, or BSA. A nonlinear least squares regression was attempted using the more general model

$\mathrm{TBV}=\mathrm{a}+\mathrm{b} \times$ weight $+\mathrm{c} \times$ height $^{\mathrm{d}}$,

where $a, b, c$ and $d$ are constants. The nonlinear regression using post-adolescent females $(296$ subjects aged 13 y or older) yields

$\operatorname{TBV}(\mathrm{L})=0.7716+0.0343 \times$ weight $(\mathrm{kg})+0.1385 \times[\text { height }(\mathrm{m})]^{4.257}$, with $\mathrm{r}^{2}=\mathbf{0 . 5 2}$. The corresponding equation for males (677 subjects aged $14 \mathrm{y}$ or older) is $\operatorname{TBV}(\mathrm{L})=1.6832+0.0299 \times$ weight $(\mathrm{kg})+0.0849 \times[\text { height }(\mathrm{m})]^{4.953}$, with $r^{2}=0.59$. These equations do not appear to improve multiple linear regressions using weight and the cube of height or using weight and height; the corresponding $r^{2}$ values are the same to two decimal places. Regression equations for post-adolescent females are

$\operatorname{TBV}(\mathrm{L})=0.3394+0.0343 \times$ weight $(\mathrm{kg})+0.3574 \times[\text { height }(\mathrm{m})]^{3}$ and

$\operatorname{TBV}(\mathrm{L})=-2.4854+0.0346 \times$ weight $(\mathrm{kg})+0.0268 \times$ height $(\mathrm{cm})$.

The corresponding equations for males are

$\operatorname{TBV}(\mathrm{L})=0.8278+0.0297 \times$ weight $(\mathrm{kg})+0.4183 \times[\text { height }(\mathrm{m})]^{3}$

and

TBV $(\mathrm{L})=-3.4722+0.0298 \times$ weight $(\mathrm{kg})+0.0374 \times$ height $(\mathrm{cm})$. 


\section{CARDIAC OUTPUT AND CARDIAC INDEX}

Although there has been considerable debate concerning the proper method of standardization of $\mathrm{CO}$ with respect to body parameters, the most common method is the cardiac index (CI), which is defined to be the quotient of $\mathrm{CO}(\mathrm{L} / \mathrm{min})$ and BSA $\left(\mathrm{m}^{2}\right)$. The original reason for using $\mathrm{CI}$ as the method of standardization was that the human basal metabolic rate is expressed in terms of surface area and basal $\mathrm{CO}$ is expected to be directly related to the basal metabolic rate (Guyton et al. 1973).

Many investigators have suggested that a multiple regression of $\mathrm{CO}$ on several variables such as height, weight, or age would be more appropriate than using BSA as the standard for comparison. Krovetz and Goldbloom (1972), using data on 115 normal subjects 1 month to 20 years of age, concluded that height was a better predictor of CO than BSA and found that height had a slightly higher correlation coefficient. Guyton et al. (1973) suggested (weight) ${ }^{0.75}$ as a standard based on results of animal studies. An analysis of published data on $\mathrm{CO}$ in normal individuals would seem to indicate that no single method of standardization with respect to body size will yield comparable values for a 'standardized cardiac output' for both sexes over the entire age range. However, since $\mathrm{CI}$ is widely used to express cardiac output, reference values are presented for both $\mathrm{CO}$ and $\mathrm{CI}$.

Although there are a variety of invasive and non-invasive methods available for measuring $\mathrm{CO}$, attention here is restricted to studies using either direct Fick or indicator dilution techniques. Non-invasive procedures such as the Doppler method, radionuclide injections, impedance cardiography, or echocardiography are not yet considered to be sufficiently reliable to be used to determine reference values (Conway 1990). Invasive procedures used to determine CO involve either the Fick principle, dye-dilution, or thermodilution. Studies that compare Fick or dye-dilution estimates of $\mathrm{CO}$ with thermodilution estimates generally show a high positive correlation with $\mathrm{r}^{2}$ ranging from 0.70 to 0.99 (Kadota 1985, Riedinger and Shellock 1984), but other studies have shown that thermodilution can substantially overestimate dye-dilution determined CO (de Leeuw and Birkenhăger 1990, Russell et al. 1990). For these reasons, reference values for supine resting CO are based on studies providing individual values for each subject and using either the Fick principle or dye-dilution (Adams and Lind 1957, Anthonisen and Crone 1959, Barratt-Boyes and Wood 1957 1958, Bevegard et al. 1966, Bickelmann et al. 1963, Bing et al. 1950, Bolomey et al. 1949, Brotmacher and Fleming 1957, Cayler et al. 1963, Chapman et al. 1950, Chapman and Fraser 1954a 1954b, 
Cournand et al. 1945, Donald et al. 19531955 1957, Doyle et al. 1951, Ebert et al. 1949, Emmanouilides et al. 1970, Etsten and Li 1954 1955, Freedman et al. 1955, Fries et al. 1952, Gessner et al. 1965, Granath and Strandell 1964, Granath et al. 1964, Grimby et al. 1966, Hamilton et al. 1948, Holmgren el al. 1960, Kattus et al. 1955, Kennedy et al. 1966, Kowalski et al. 1954, Levine et al. 1962, Levinson et al. 1966, Lucas et al. 1961, McGregor et al. 1961, Muiesan et al. 1968, Myers 1947, Norryd et al. 1974, Nylin et al. 1961, Reeves et al. 1961a 1961b, Regan et al. 1961, Riley et al. 1948, Ross et al. 1966, Rotta et al. 1956, Schnabel et al. 1959, Shaver et al. 1968, Shepherd et al. 1955, Slonim et al. 1954, Sproul and Simpson 1964, Stead et al. 1945, Stenberg et al. 1967, Thomas et al. 1962, Thomasson 1957, Werko et al. 1949).

\section{A. Cardiac Output}

Summary statistics of $\mathrm{CO}$ data for studies that enumerated values for individual subjects are presented in Table 3. The trimmed means were computed by taking the average of the values that remained after the highest $20 \%$ and lowest $20 \%$ of the values were deleted in each age range. The standard deviations of the individual values were computed using all the available data.

Over the entire age range ( $1 \mathrm{~d}$ to $85 \mathrm{y}$ ), the correlation in each sex category between $\mathrm{CO}$ and any one of the variables weight, height, or BSA is greater than 0.6. The correlation between $\mathrm{CO}$ and BSA is roughly the same as that for either of the other variables including (weight) ${ }^{0.75}$.

A multiple linear regression analysis over the entire age range is not appropriate because there is a strong nonlinear relationship between $\mathrm{CO}$ and age. The nonlinearity is particularly evident when $\mathrm{CO}$ is standardized with respect to a measure of body size such as BSA or height. In age subintervals for adults on which the relationships between $\mathrm{CO}$ and other variables appear to be linear (age 20-60 y), the individual variation in $\mathrm{CO}$ appears to be much greater that the variation that can be explained by a measure of body size. For adult males, BSA and age appear to be better predictors of $\mathrm{CO}$ than linear combinations of age, weight, or height, and for females for which all variables (age, weight, height, and BSA) were reported, BSA appears to be the best predictor. However, for either sex type, less than five percent of the total variation in adult $\mathrm{CO}$ is explained by the regression. The linear least squares regression using 415 males aged 20 to 60 y gives

$$
\mathrm{CO}(\mathrm{L} / \mathrm{min})=4.067+\left[1.665 \times \mathrm{BSA}\left(\mathrm{m}^{2}\right)\right]-[0.017 \times \text { Age }(\mathrm{y})]
$$

with $r^{2}=0.05$. The regression using 143 females aged 20 to 60 y gives

$$
\mathrm{CO}(\mathrm{L} / \mathrm{min})=3.396+\left[1.565 \times \mathrm{BSA}\left(\mathrm{m}^{2}\right)\right]
$$

with $r^{2}=0.02$. 
Table 3. Summary of reported values of cardiac output within age groups, computed using either direct Fick or indicator dilution techniques.

\begin{tabular}{||c|c|c|c|c|c|c|c|c||}
\hline \multirow{2}{*}{$\begin{array}{c}\text { Age range } \\
\text { (y) }\end{array}$} & \multicolumn{9}{|c|}{ Males } & \multicolumn{4}{|c|}{ Females } \\
\cline { 2 - 11 } & mean & s.d. & number & $\begin{array}{c}\text { trimmed } \\
\text { mean }\end{array}$ & mean & s.d. & number & $\begin{array}{c}\text { trimmed } \\
\text { mean }\end{array}$ \\
\hline $0.00-0.02$ & $0.57 *$ & 0.2 & 46 & $0.56 *$ & $0.57 *$ & 0.2 & 46 & $0.56 *$ \\
\hline $0.04-0.40$ & $0.75 *$ & 0.3 & 6 & $0.73 *$ & $0.75 *$ & 0.3 & 6 & $0.73 *$ \\
\hline $0.6-1.0$ & $1.14 *$ & 0.2 & 2 & & $1.14 *$ & 0.2 & 2 & \\
\hline $1.7-4.0$ & $2.47 *$ & 0.8 & 6 & $2.39 *$ & $2.47 *$ & 0.8 & 6 & $2.39 *$ \\
\hline $5.0-7.0$ & $3.85 *$ & 1.1 & 22 & $3.69 *$ & $3.85 *$ & 1.1 & 22 & $3.69 *$ \\
\hline $8.0-9.5$ & $4.70 *$ & 1.4 & 16 & $4.57 *$ & $4.70 *$ & 1.4 & 16 & $4.57 *$ \\
\hline $10-12$ & 4.96 & 0.9 & 5 & 4.63 & 4.92 & 1.2 & 14 & 4.82 \\
\hline $13-15$ & 5.93 & 1.6 & 11 & 6.07 & 6.01 & 1.1 & 3 & \\
\hline $16-19$ & 6.64 & 1.5 & 46 & 6.64 & 6.33 & 1.4 & 17 & 6.21 \\
\hline $20-29$ & 6.98 & 1.5 & 170 & 6.92 & 6.04 & 1.6 & 71 & 5.91 \\
\hline $30-39$ & 6.53 & 1.7 & 121 & 6.41 & 5.63 & 1.3 & 34 & 5.54 \\
\hline $40-49$ & 6.31 & 1.4 & 84 & 6.25 & 5.95 & 1.3 & 25 & 5.94 \\
\hline $50-99$ & 6.42 & 1.5 & 42 & 6.33 & 6.51 & 1.5 & 11 & 6.40 \\
\hline $60-69$ & 5.89 & 1.5 & 26 & 5.73 & 5.36 & 1.8 & 11 & 5.17 \\
\hline $70-79$ & 5.79 & 0.9 & 11 & 5.74 & & & & \\
\hline $80-83$ & 5.15 & 0.4 & 2 & & & & & \\
\hline
\end{tabular}

*Values for males and females were combined in these age groups. 
The situation is somewhat different for children. For newborns, none of the regressions of $\mathrm{CO}$ on weight, height or BSA are significant. For children age 0.2 to 4 y (10 subjects), no studies reporting both $\mathrm{CO}$ and height or weight were found. Linear least squares regressions of $\mathrm{CO}$ on age or BSA seem appropriate:

$$
\mathrm{CO}(\mathrm{L} / \mathrm{min})=0.734+[0.563 \times \text { Age }(\mathrm{y})]
$$

with $r^{2}=0.75$ and

$$
\mathrm{CO}(\mathrm{L} / \mathrm{min})=-0.514+\left[5.223 \times \mathrm{BSA}\left(\mathrm{m}^{2}\right)\right]
$$

with $r^{2}=0.61$.

For older children (age 5 to $19 \mathrm{y}$ ) a nonlinear regression was attempted on the combined sex groups using weight as the predictor. The corrected $r^{2}$ is 0.81 and the regression equation is

$\mathrm{CO}(\mathrm{L} / \mathrm{min})=3.107+\left\{0.012 \times[\text { Weight }(\mathrm{kg})]^{1.369}\right\}$.

Some of the criticisms of BSA as a method of CO standardization stem from the fact that BSA is generally not measured but rather estimated as a nonlinear function of height and weight (or other easily measured variables). Such methods do not take into account the difference in body contours among the sexes and they tend to underestimate BSA in children and adult males and overestimate BSA in adult females (Krovetz 1965). For children, standardization with respect to BSA, weight, height, or age can be quite useful in predicting $\mathrm{CO}$. In adults little is to be gained by standardization with respect to a measure of body size except for the fact that the division of $\mathrm{CO}$ by BSA (or estimated BSA) does appear to provide comparable distributions of values at a given age in the two sex types.

\section{B. Cardiac Index}

Summary statistics of $\mathrm{CI}$ data for studies that enumerated values for individual subjects are presented in Table 4. For studies that provided $\mathrm{CO}$, height, and weight for each individual, BSA was estimated using the equations of Gehan and George (1970). Trimmed means and standard deviations were computed as described above for $\mathrm{CO}$.

A number of researchers (Brandfonbrener et al. 1955, Cournand et al. 1945, Granath and Strandell 1964, Jegier et al. 1963, Julius et al. 1967, Katori 1979, Krovetz and Goldbloom 1972, Kuikka and Lansimies 1982, Lammerant et al. 1961, Luisada et al. 1980) measured CI of individuals to investigate the relationship between $\mathrm{CI}$ and age. Although there is substantial quantitative variation in the results, most researchers observed either a linear or nonlinear decrease in CI with age. Although some of the disparate findings can be ascribed to the difference in technique, much 
Table 4. Summary of reported values of cardiac index within age groups, computed using either direct Fick or indicator dilution techniques.

\begin{tabular}{|r|r|r|r|r|r|r|r|r||}
\hline \multirow{2}{*}{$\begin{array}{c}\text { Age range } \\
\text { (y) }\end{array}$} & \multicolumn{3}{|c|}{ Males } & \multicolumn{3}{c|}{ Females } & \multicolumn{2}{c|}{ Males and Females } \\
\cline { 2 - 10 } & mean & s.d. & number & mean & s.d. & number & $\begin{array}{r}\text { trimmed } \\
\text { mean }\end{array}$ & number \\
\hline \hline $0.00-0.02$ & 2.91 & 0.9 & 16 & 2.90 & 1.0 & 16 & 2.81 & 46 \\
\hline $0.04-0.40$ & & & & 2.76 & & 1 & 3.58 & 6 \\
\hline $0.6-1.0$ & & & & & & & 3.20 & 2 \\
\hline $1.7-4.0$ & & & & & & & 4.40 & 6 \\
\hline $5.0-7.0$ & 4.30 & 0.6 & 5 & 4.70 & 1.4 & 7 & 4.52 & 22 \\
\hline $8.0-9.5$ & 4.58 & 1.0 & 7 & 4.86 & 1.1 & 3 & 4.57 & 16 \\
\hline $10-12$ & 4.98 & 1.1 & 5 & 4.36 & 1.2 & 14 & 4.63 & 25 \\
\hline $13-15$ & 3.56 & 1.0 & 11 & 4.13 & 0.5 & 3 & 4.06 & 21 \\
\hline $16-19$ & 3.75 & 0.9 & 46 & 4.03 & 0.8 & 17 & 3.80 & 67 \\
\hline $20-29$ & 3.71 & 0.8 & 170 & 3.77 & 1.1 & 71 & 3.68 & 260 \\
\hline $30-39$ & 3.46 & 0.9 & 121 & 3.56 & 0.7 & 34 & 3.43 & 170 \\
\hline $40-49$ & 3.43 & 0.7 & 84 & 3.70 & 0.8 & 25 & 3.43 & 119 \\
\hline $50-59$ & 3.55 & 0.8 & 42 & 4.08 & 1.0 & 11 & 3.58 & 58 \\
\hline $60-69$ & 3.19 & 0.8 & 26 & 3.18 & 0.9 & 11 & 3.16 & 38 \\
\hline $70-79$ & 3.11 & 0.5 & 11 & & & & 3.08 & 12 \\
\hline $80-83$ & 2.99 & 0.1 & 2 & & & & & \\
\hline
\end{tabular}


of the diversity is due to the variation in basal $\mathrm{CO}$ among similar individuals and even the variation possible in the values of a single individual. Studies that considered large numbers of individuals at several different ages suffered from the fact that there were too few individuals in any small age interval. Also, the studies that included adults have few if any values for the young child. By looking at three studies, Prec and Cassels (1955) for infants, Brotmacher and Fleming (1957) for youths, and Brandfonbrener et al. (1955) for adults, Guyton et al. (1973) gave a curve which provides the approximate shape of the average male $\mathrm{CI}$ as a function of age. There is a sharp increase in the average $\mathrm{CI}$ until the age of 4 or $5 \mathrm{y}$ with a leveling off until around the age of 10 or $11 \mathrm{y}$. The average $\mathrm{CI}$ falls sharply during the teen years followed by more gradual decreases from age $20 \mathrm{y}$ to age $60 \mathrm{y}$, and there is another more rapid decrease at about age $60 \mathrm{y}$.

There does not appear to be a difference in the male and female average $\mathrm{CI}$ values at a given age except possibly for those years around the fifth decade of life. There is a significant difference between the average male and average female $C I$ values in both the $40-49 \mathrm{y}$ and 50-59 y age groups (p-values 0.06 and 0.03 respectively using two-sample t-tests). The nonparametric KolmogorovSmirnov two-sample test also indicates a significant difference in the male and female $\mathrm{CI}$ distributions in the 50-59 y age group. None of the other intervals have male and female CI averages which appear to be significantly different, although individual information for the first few years of life is sparse. The individual values of female $\mathrm{CI}$ indicate that there may be an increase in the female CI in the 40-60 y age range, but the sample size is small and neither of the earlier mentioned parametric or nonparametric tests indicate significant differences in the female $\mathrm{CI}$ values during the third, fourth and fifth decades of life. Furthermore, longitudinal studies of Katori (1979), Kuikka and Lansimies (1982) and Luisada et al. (1980) do not indicate an increase in female CI with age during adulthood. It may be that the observed increase in the trimmed mean adult female $\mathrm{CI}$ is due to random fluctuations in the data.

\section{Reference Values for $\mathrm{CO}$ and $\mathrm{CI}$}

Table 5 contains suggested reference values for $\mathrm{CO}$ and $\mathrm{CI}$ as a function of age and sex. Reference values for male and female CI through age $40 \mathrm{y}$ are based on the trimmed mean CI that was computed using all available data. Because of the possible sex difference near the fifth decade of life, male reference values for higher ages are based on the trimmed mean CI for males. It is assumed that the average female CI remains relatively constant throughout the 35-55 y age range. The data is inadequate to make reliable statements about the average female $\mathrm{CI}$ for older adults. 
Table 5. Suggested reference values for cardiac output and cardiac index.

\begin{tabular}{|c|c|c|c|c|c|c|c|c|}
\hline \multirow[b]{3}{*}{$\begin{array}{r}\text { Age } \\
\text { (y) } \\
\end{array}$} & \multicolumn{4}{|c|}{ Cardiac Output (L. $\left.\min ^{-1}\right)$} & \multicolumn{4}{|c|}{ Cardiac Index $\left(\mathrm{L} \cdot \mathrm{min}^{-1} \cdot \mathrm{m}^{-2}\right)$} \\
\hline & \multicolumn{2}{|c|}{ Males } & \multicolumn{2}{|c|}{ Females } & \multicolumn{2}{|c|}{ Males } & \multicolumn{2}{|c|}{ Females } \\
\hline & mean & s.d. & mean & s.d. & mean & s.d. & mean & s.d. \\
\hline 0 & 0.6 & 0.2 & 0.6 & 0.2 & 2.8 & 0.9 & 2.8 & 0.9 \\
\hline 1 & 1.2 & 0.4 & 1.2 & 0.4 & 3.6 & 0.9 & 3.6 & 0.9 \\
\hline 3 & 2.5 & 0.9 & 2.5 & 0.9 & 4.3 & 1.3 & 4.3 & 1.3 \\
\hline 6 & 3.9 & 1.1 & 3.9 & 1.1 & 4.5 & 1.3 & 4.5 & 1.3 \\
\hline 10 & 5.0 & 1.3 & 5.0 & 1.3 & 4.6 & 1.3 & 4.6 & 1.3 \\
\hline 14 & 6.0 & 1.5 & 6.0 & 1.4 & 4.1 & 1.3 & 4.1 & 1.3 \\
\hline 18 & 6.6 & 1.5 & 6.3 & 1.4 & 3.8 & 1.0 & 3.8 & 1.0 \\
\hline 24 & 7.0 & 1.5 & 6.0 & 1.4 & 3.7 & 0.9 & 3.7 & 0.9 \\
\hline 34 & 6.5 & 1.5 & 5.9 & 1.4 & 3.6 & 0.9 & 3.6 & 0.9 \\
\hline 44 & 6.4 & 1.5 & 5.9 & 1.4 & 3.5 & 0.8 & 3.6 & 0.9 \\
\hline 54 & 6.4 & 1.5 & 5.9 & 1.4 & 3.4 & 0.8 & 3.6 & 0.9 \\
\hline 64 & 5.9 & 1.5 & & & 3.2 & 0.7 & & \\
\hline 74 & 5.8 & 1.4 & & & 3.1 & 0.7 & & \\
\hline
\end{tabular}


Reference values for $\mathrm{CO}$ are assumed to be independent of sex until near age $10 \mathrm{y}$. Reference values for female $\mathrm{CO}$ are based on the trimmed mean $\mathrm{CO}$ for females through age $35 \mathrm{y}$. The average female $\mathrm{CO}$ from age $35 \mathrm{y}$ to $55 \mathrm{y}$ is assumed to be relatively constant. The individual data values for $\mathrm{CI}$ and $\mathrm{CO}$ as a function of age are compared with reference curves for each sex in Figures 1-4; curves representing one standard deviation from the reference curve are also included. The reference curves for male and female CI are compared with reference curves suggested by data of other authors in Figures 5 and 6 . Most of the longitudinal studies depicted in Figures 5 and 6 (Kuikka and Lansimies 1982, Lammerant et al. 1961, Luisada et al. 1980) used methods other than direct Fick or dye-injection for measuring $\mathrm{CO}$.

\section{Cardiac output and body position}

Although most of the $\mathrm{CO}$ studies reported in the literature contain values of $\mathrm{CO}$ measured with the subject recumbent, several researchers have considered the effect on CO of movement to a position other than the horizontal position (Bevegard et al. 1966, Boer et al. 1979, Donald et al. 1953, Gilmore et al. 1952, Granath et al. 1961, Granath et al. 1964, Grimby et al. 1966, Hanson et al. 1968, Hartley et al. 1969, Julius et al. 1967, Lehtovirta et al. 1972, Levinson et al. 1966, McGregor et al. 1961, McMichael and Sharpey-Schafer 1944, Murata et al. 1981, Ohlsson et al. 1983, Pyorala 1966, Rankin et al. 1975, Reeves et al. 1961a, Segel et al. 1973, Smith et al. 1970, Stead et al. 1945, Stenberg et al. 1967, Tuckman and Shillingford 1966, Wang et al. 1960, Weissler et al. 1957). All the studies report an average decrease in the $\mathrm{CO}$ associated with a movement away from horizontal, even though there were some individual exceptions (possibly due to change in anxiety level). In some of the studies, the subjects were strapped to a table which could be rotated to give various degrees of tilt away from horizontal; other studies considered the effect of movement from a horizontal position to a sitting or standing position. It appears that the resting $\mathrm{CO}$ peaks at the horizontal position.

The weighted average (weighted by the number of subjects) decrease in $\mathrm{CO}$ is $18 \%$ (range of $5 \%$ to $30 \%$ ) when the subject moves from the horizontal to a seated position (Bevegard et al. 1966, Donald et al. 1953, Granath et al. 1961, Granath et al. 1964, Grimby et al. 1966, Hartley et al. 1969, Julius et al. 1967, McGregor et al. 1961, Ohlsson et al. 1983, Stenberg et al. 1967). The average decrease is $23 \%$ (range of $16 \%$ to $38 \%$ ) when the subject moves from the horizontal to a standing position (Hanson et al. 1968, McMichael and Sharpey-Schafer 1944, Reeves et al. 1961a, Wang et al. 1960). 
Figure 1. Age related changes in male supine cardiac output are depicted. Individual measurements are compared to the suggested reference curve (solid line) and curves that lie one standard deviation away from the reference curve (dotted lines).

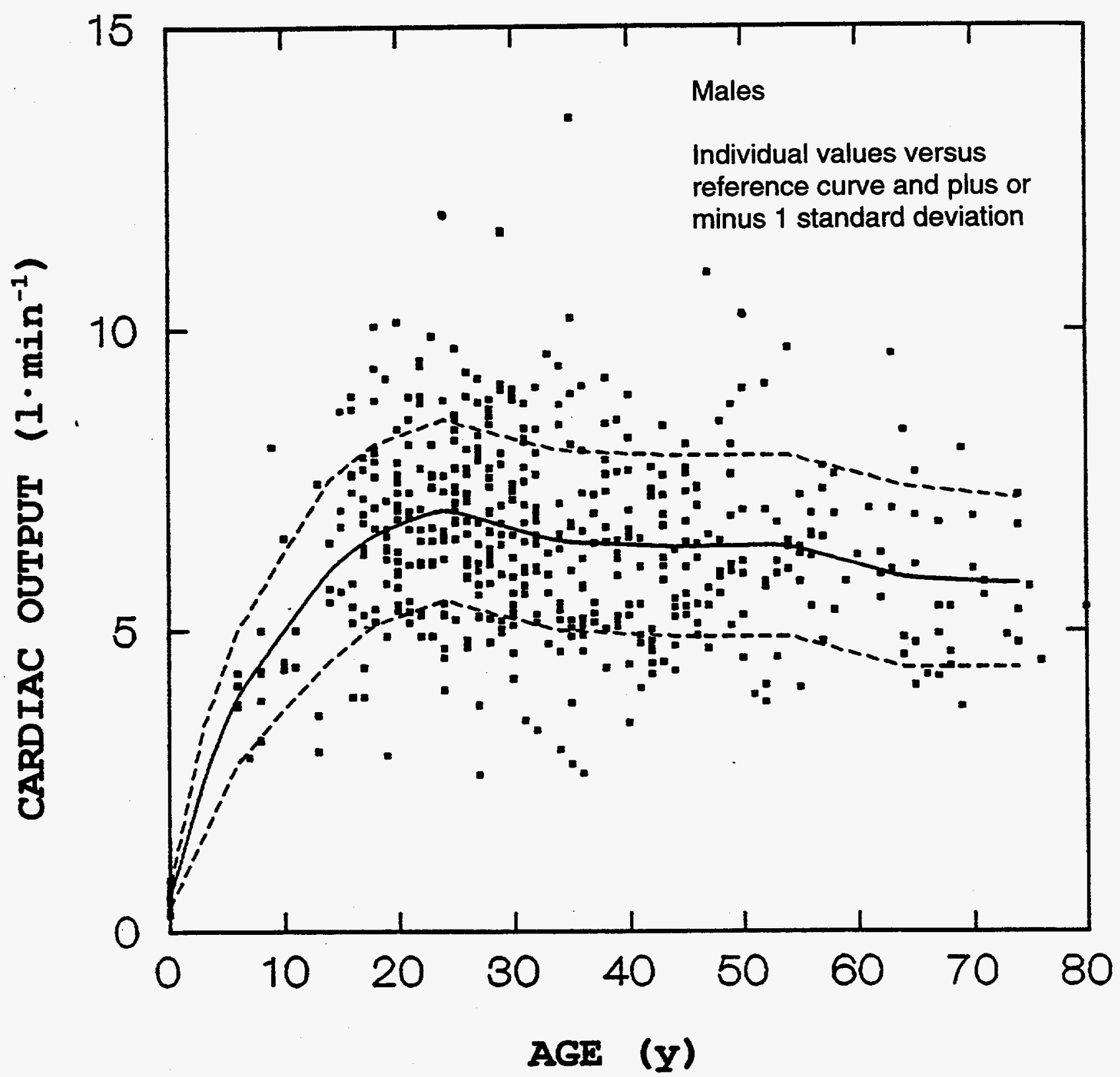


Figure 2. Age related changes in female supine cardiac output are depicted. Individual measurements are compared to the suggested reference curve (solid line) and curves that lie one standard deviation away from the reference curve (dotted lines).

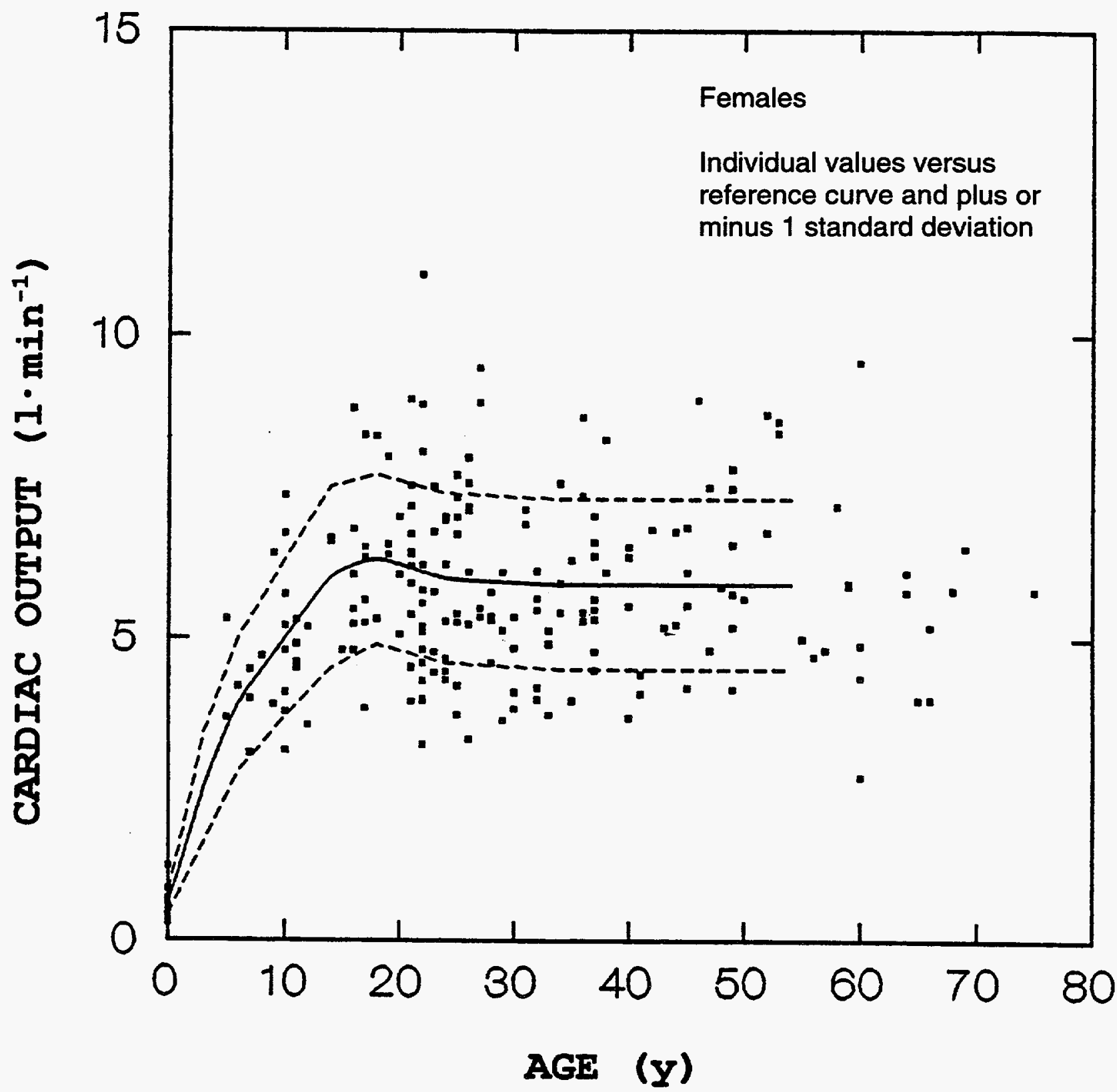


Figure 3. Age related changes in male supine cardiac index are depicted. Individual measurements are compared to the suggested reference curve (solid line) and curves that lie one standard deviation away from the reference curve (dotted lines).

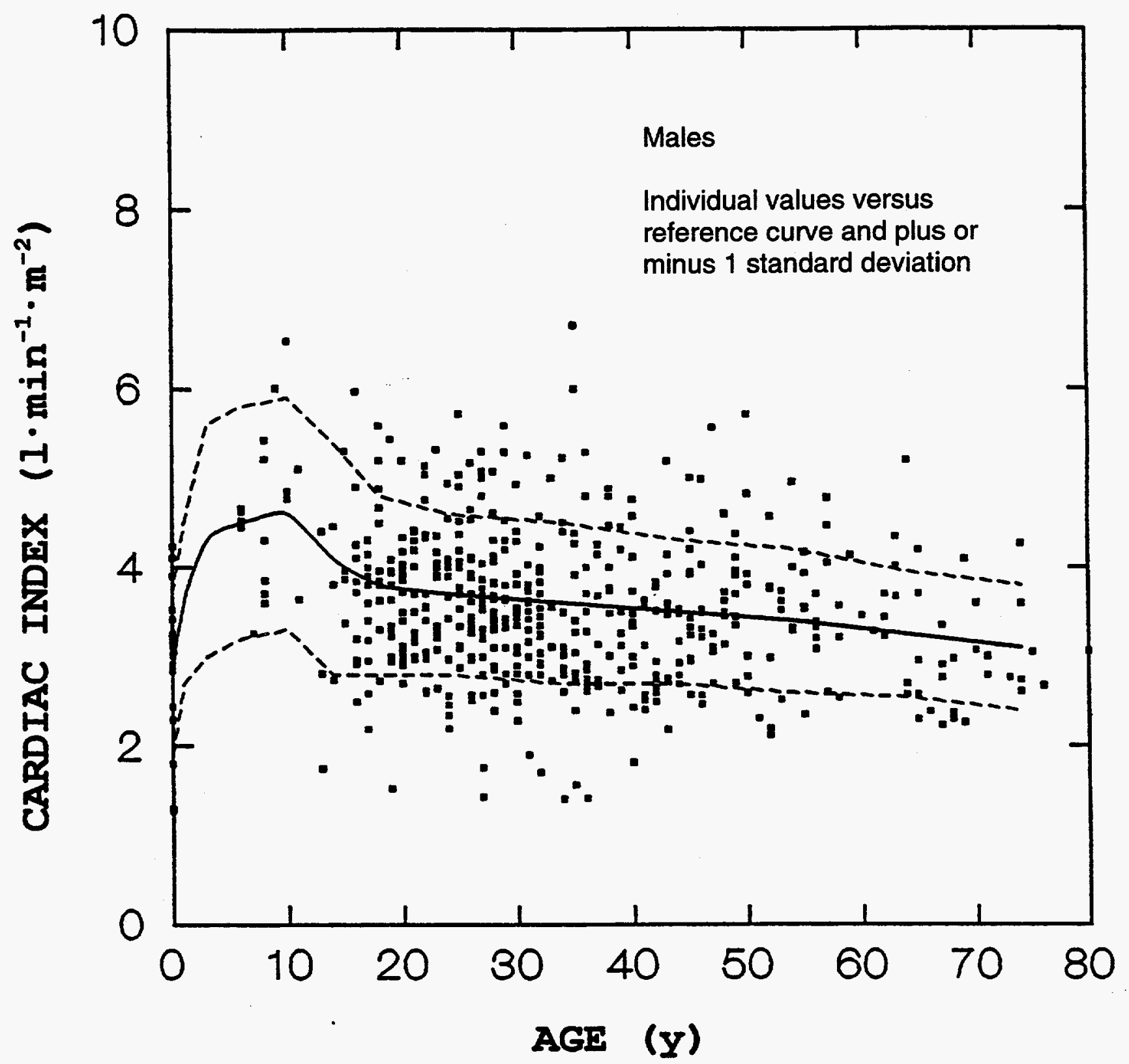


Figure 4. Age related changes in female supine cardiac index are depicted. Individual measurements are compared to the suggested reference curve (solid line) and curves that lie one standard deviation away from the reference curve (dotted lines).

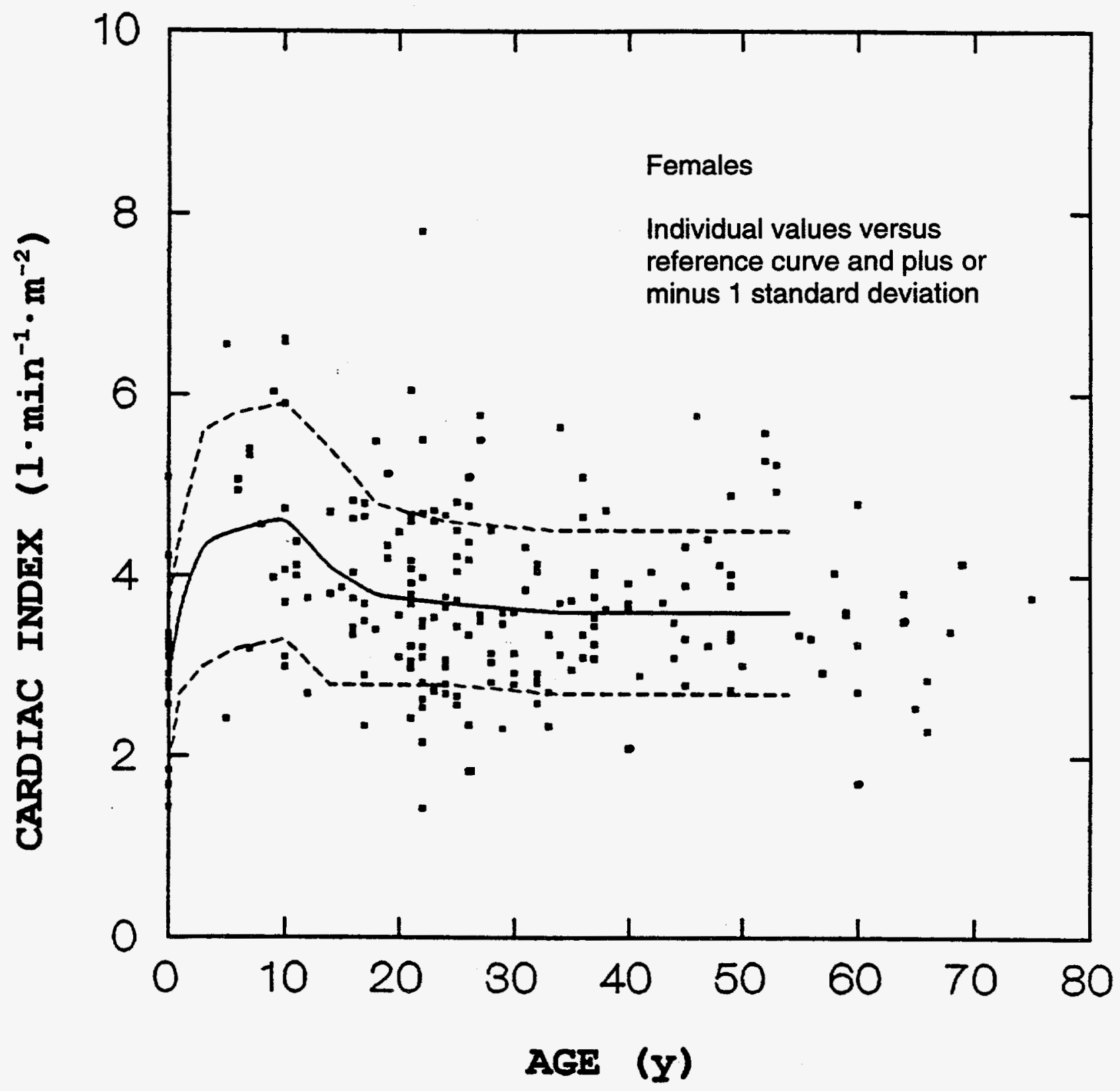


Figure 5. The suggested reference curve (solid line) for male supine cardiac index is compared to curves based on average values from studies on subjects in several different age groups.

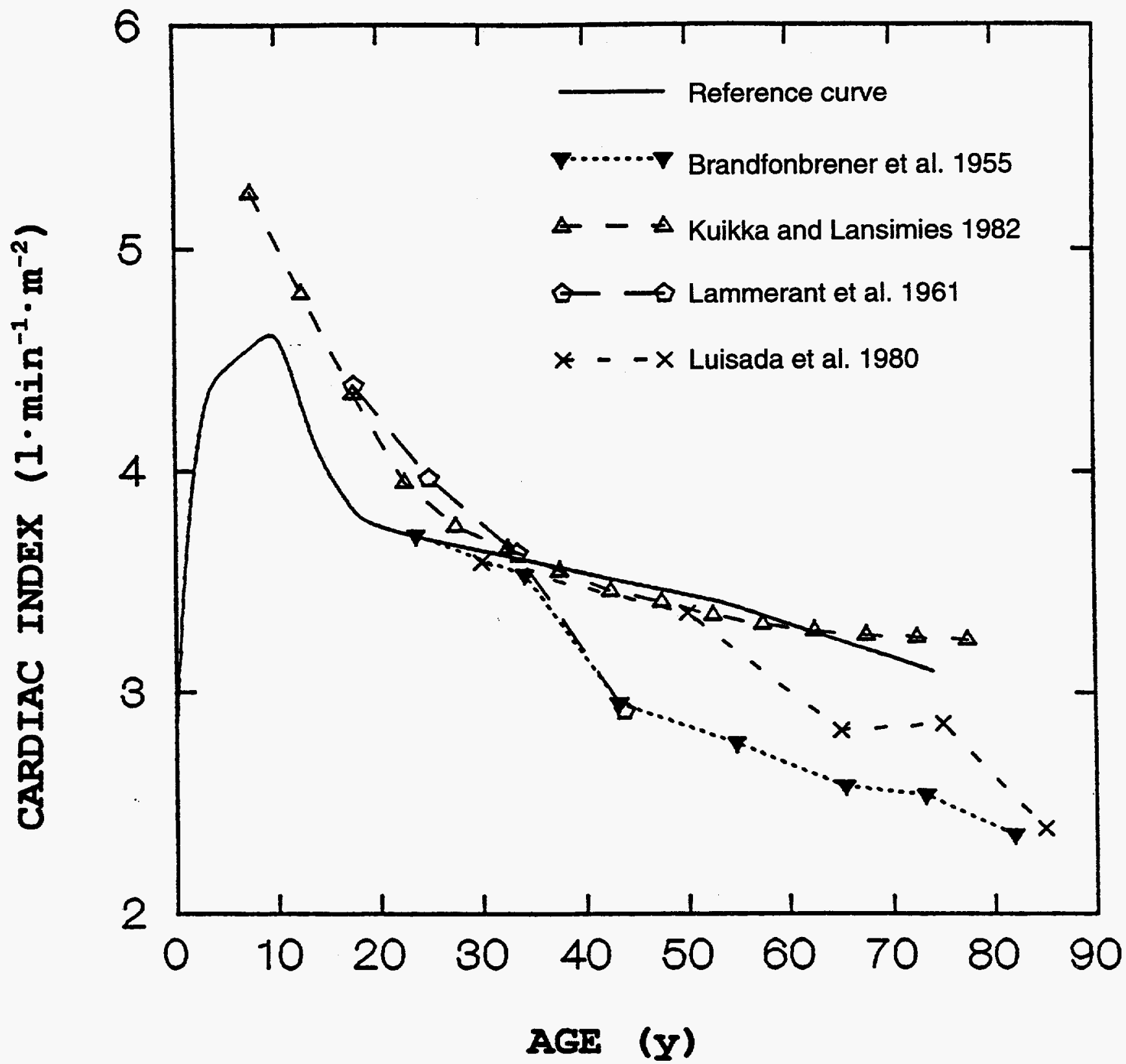


Figure 6. The suggested reference curve (solid line) for female supine cardiac index is compared to curves based on average values from studies on subjects in several different age groups.

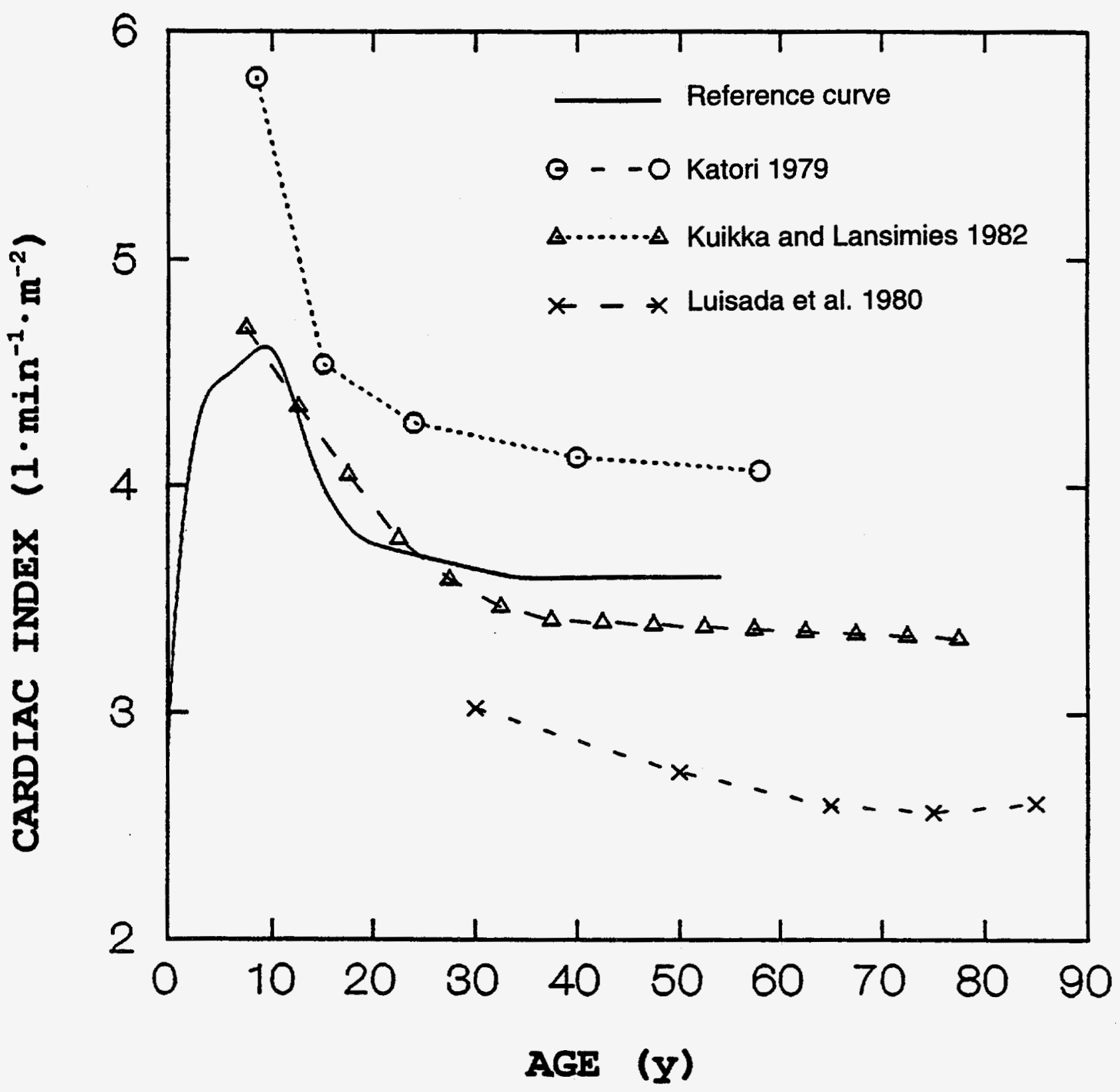


The results from studies which rotated the subjects through various degrees of tilt are reported in Table 6. A tilt of as much as 10 degrees away from the horizontal will apparently decrease the $\mathrm{CO}$ by approximately $5 \%$, and a tilt of 20 to 30 degrees produces a $\mathrm{CO}$ similar to the seated value. The decrease in $\mathrm{CO}$ when the subject is tilted by 45 degrees or more is comparable to the decrease caused by standing.

\section{E. Cardiac output and exercise}

Cardiac output increases dramatically in response to heavy exercise. At higher levels of oxygen uptake, a unit increase in oxygen uptake produces a smaller increase in $\mathrm{CO}$ than that produced at lower levels of oxygen uptake. However, the relationship between oxygen uptake and $\mathrm{CO}$ appears to be approximately linear if attention is restricted to certain subintervals of oxygen uptake values.

Regressions of $\mathrm{CO}(\mathrm{L} / \mathrm{min})$ or $\mathrm{CI}\left(\mathrm{L} / \mathrm{min} / \mathrm{m}^{2}\right)$ on oxygen uptake $(\mathrm{L} / \mathrm{min})$ were obtained from studies that reported individual values and used direct Fick or indicator dilution techniques (Astrand et al. 1964, Barratt-Boyes and Wood 1957, Donald et al. 1955 1957, Ekblom et al. 1968, Freedman et al. 1955, Holmgren et al. 1960, Klausen 1966, Kowalski et al. 1954, Levine et al. 1962, Reeves et al. 1961a 1961b, Riley et al. 1948, Ross et al. 1966, Tabakin et al. 1964). The assumptions of linear regression appear to be met if attention is restricted to oxygen uptake values less than $0.7 \mathrm{~L} / \mathrm{min}$ or if attention is restricted to oxygen uptake values greater than $0.7 \mathrm{~L} / \mathrm{min}$ (see Figures 7-11), but the slopes of the relationships are clearly different on these two intervals. Male and female values can be combined in all the regressions except for $\mathrm{CO}$ and oxygen uptake at low work levels.

The linear least squares regression of $\mathrm{CO}$ on oxygen uptake for males (226 data pairs) yields

$$
\mathrm{CO}(\mathrm{L} / \mathrm{min})=4.0+10 \times \mathrm{VO}_{2}(\mathrm{~L} / \mathrm{min}) \quad\left(\mathrm{VO}_{2} \leq 0.7 \mathrm{~L} / \mathrm{min}\right)
$$

with $r^{2}=0.35$. For females (104 data pairs), the corresponding regression is $\quad \mathrm{CO}(\mathrm{L} / \mathrm{min})=$ $4.1+8.4 \times \mathrm{VO}_{2}(\mathrm{~L} / \mathrm{min}) \quad\left(\mathrm{VO}_{2} \leq 0.7 \mathrm{~L} / \mathrm{min}\right)$

with $\mathrm{r}^{2}=\mathbf{0 . 5 1}$. The corresponding regression of $\mathrm{CI}$ for males and females ( 330 data pairs) yields

$$
\mathrm{CI}\left(\mathrm{L} / \mathrm{min} / \mathrm{m}^{2}\right)=2.4+5.1 \times \mathrm{VO}_{2}(\mathrm{~L} / \mathrm{min})\left(\mathrm{VO}_{2} \leq 0.7 \mathrm{~L} / \mathrm{min}\right)
$$

with $r^{2}=0.37$. For the 358 data pairs involving male and female $\mathrm{CO}$ and $\mathrm{CI}$ at higher values of oxygen uptake, the regressions yield

$$
\mathrm{CO}(\mathrm{L} / \mathrm{min})=7.0+4.7 \times \mathrm{VO}_{2}(\mathrm{~L} / \mathrm{min}) \quad\left(\mathrm{VO}_{2}>0.7 \mathrm{~L} / \mathrm{min}\right)
$$

with $r^{2}=0.78$ and

$$
\mathrm{CI}\left(\mathrm{L} / \mathrm{min} / \mathrm{m}^{2}\right)=4.0+2.3 \times \mathrm{VO}_{2}(\mathrm{~L} / \mathrm{min})\left(\mathrm{VO}_{2}>0.7 \mathrm{~L} / \mathrm{min}\right)
$$

with $r^{2}=0.72$ 
Table 6. Average decrease in cardiac output induced by a rotation away from a horizontal position.

\begin{tabular}{|c|c|c|c|c|c|}
\hline \multicolumn{2}{|c|}{ Age range $(y)$} & \multirow{2}{*}{$\begin{array}{l}\text { Number } \\
\text { of } \\
\text { subjects }\end{array}$} & \multirow{2}{*}{$\begin{array}{l}\text { decrease } \\
(z)\end{array}$} & \multirow{2}{*}{$\begin{array}{l}\text { Degrees } \\
\text { from } \\
\text { horizontal }\end{array}$} & \multirow[t]{2}{*}{ Reference } \\
\hline lower & upper & & & & \\
\hline 40 & 53 & 4 & 3 & 10 & $\begin{array}{l}\text { Tuckman and } \\
\text { Shillingford } 1966\end{array}$ \\
\hline 18 & 29 & 4 & 7 & 10 & $\begin{array}{l}\text { Tuckman and } \\
\text { Shillingford } 1966\end{array}$ \\
\hline 16 & 25 & 2 & 10 & 20 & $\begin{array}{l}\text { Tuckman and } \\
\text { Shillingford } 1966\end{array}$ \\
\hline 35 & 50 & 6 & 19 & 20 & $\begin{array}{l}\text { Tuckman and } \\
\text { Shillingford } 1966\end{array}$ \\
\hline-- & - & 5 & 25 & 20 & Boer et al. 1979 \\
\hline 22 & 39 & 4 & 5 & 30 & Segel et al. 1973 \\
\hline 23 & 23 & 1 & 19 & 30 & $\begin{array}{l}\text { Tuckman and } \\
\text { Shillingford } 1966\end{array}$ \\
\hline 37 & 71 & 5 & 19 & 30 & $\begin{array}{l}\text { Tuckman and } \\
\text { Shillingford } 1966\end{array}$ \\
\hline 30 & 40 & 3 & 19 & 40 & $\begin{array}{l}\text { Tuckman and } \\
\text { Shillingford } 1966\end{array}$ \\
\hline 26 & 62 & 20 & 20 & 35 & Murata et al. 1981 \\
\hline 50 & 61 & 5 & 21 & 45 & Gilmore et al. 1952 \\
\hline 30 & 33 & 2 & 34 & 45 & Gilmore et al. 1952 \\
\hline 22 & 38 & 3 & 22 & 55 & $\begin{array}{l}\text { Tuckman and } \\
\text { Shillingford } 1966\end{array}$ \\
\hline 18 & 25 & 2 & 8 & 60 & Weissler et al. 1957 \\
\hline 31 & 42 & 3 & 17 & 60 & $\begin{array}{l}\text { Tuckman and } \\
\text { Shillingford } 1966\end{array}$ \\
\hline 22 & 39 & 4 & 24 & 60 & Segel et al. 1973 \\
\hline 20 & 32 & 30 & 15 & 70 & Lehtovirta et al. 1972 \\
\hline 26 & 62 & 20 & 25 & 70 & Murata et al. 1981 \\
\hline 20 & 36 & 12 & 27 & 70 & Pyorala 1966 \\
\hline 20 & 26 & 8 & 18 & 70 & Smith et al. 1970 \\
\hline-- & -- & 5 & 24 & 70 & Stead et al. 1945 \\
\hline 20 & 35 & 10 & 30 & 75 & Rankin et al. 1975 \\
\hline 23 & 37 & 8 & 13 & 90 & Loeppky et al. 1981 \\
\hline 22 & 39 & 4 & 64 & 90 & Segel et al. 1973 \\
\hline
\end{tabular}


Figure 7. The regression line for cardiac output as a function of oxygen uptake is compared to individual male values with $\mathrm{VO}_{2}$ values less than or equal to $0.71 \cdot \mathrm{min}^{-1}$.

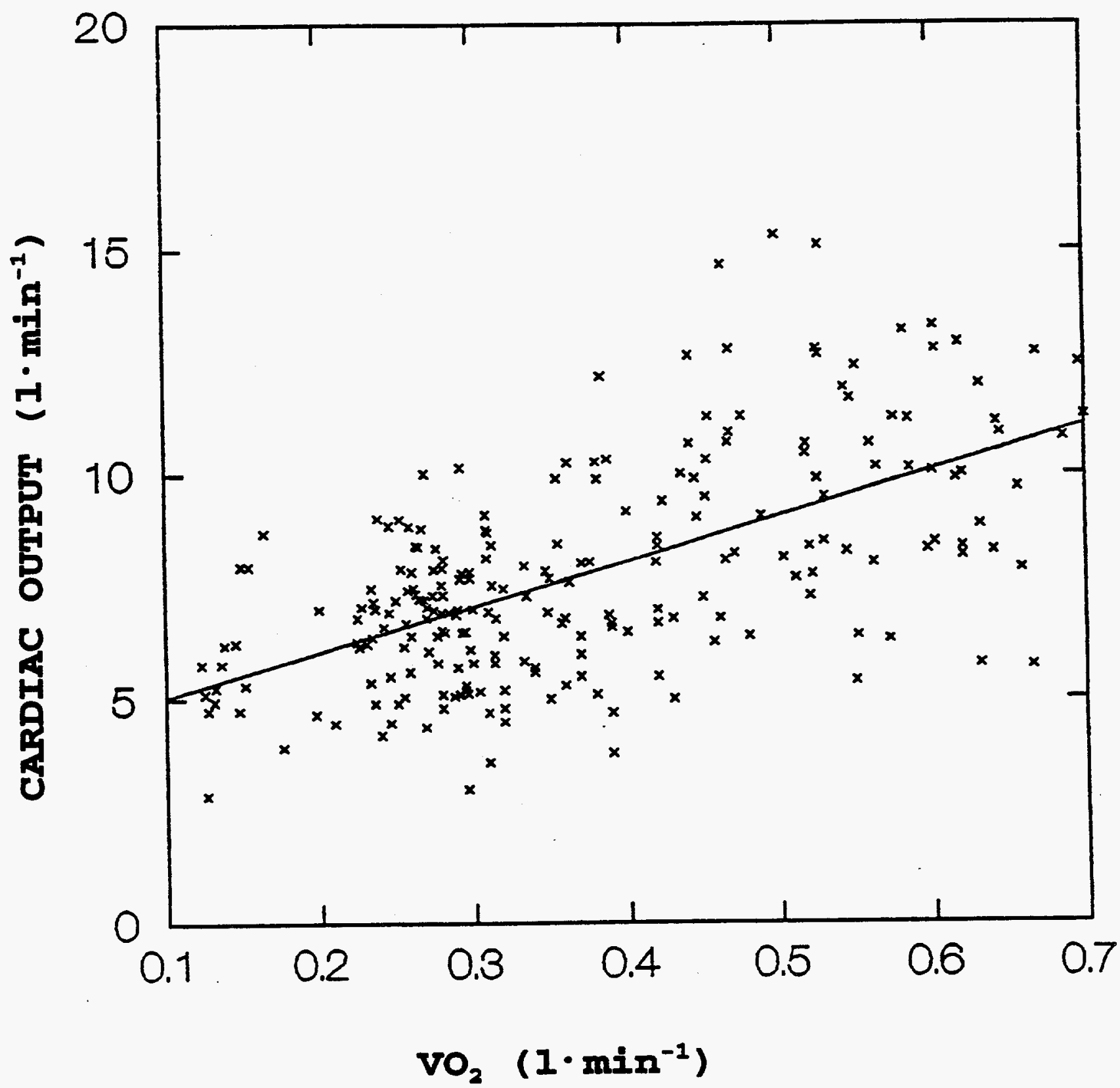


Figure 8. The regression line for cardiac output as a function of oxygen uptake is compared to individual female values with $\mathrm{VO}_{2}$ values less than or equal to $0.71 \cdot \mathrm{min}^{-1}$.

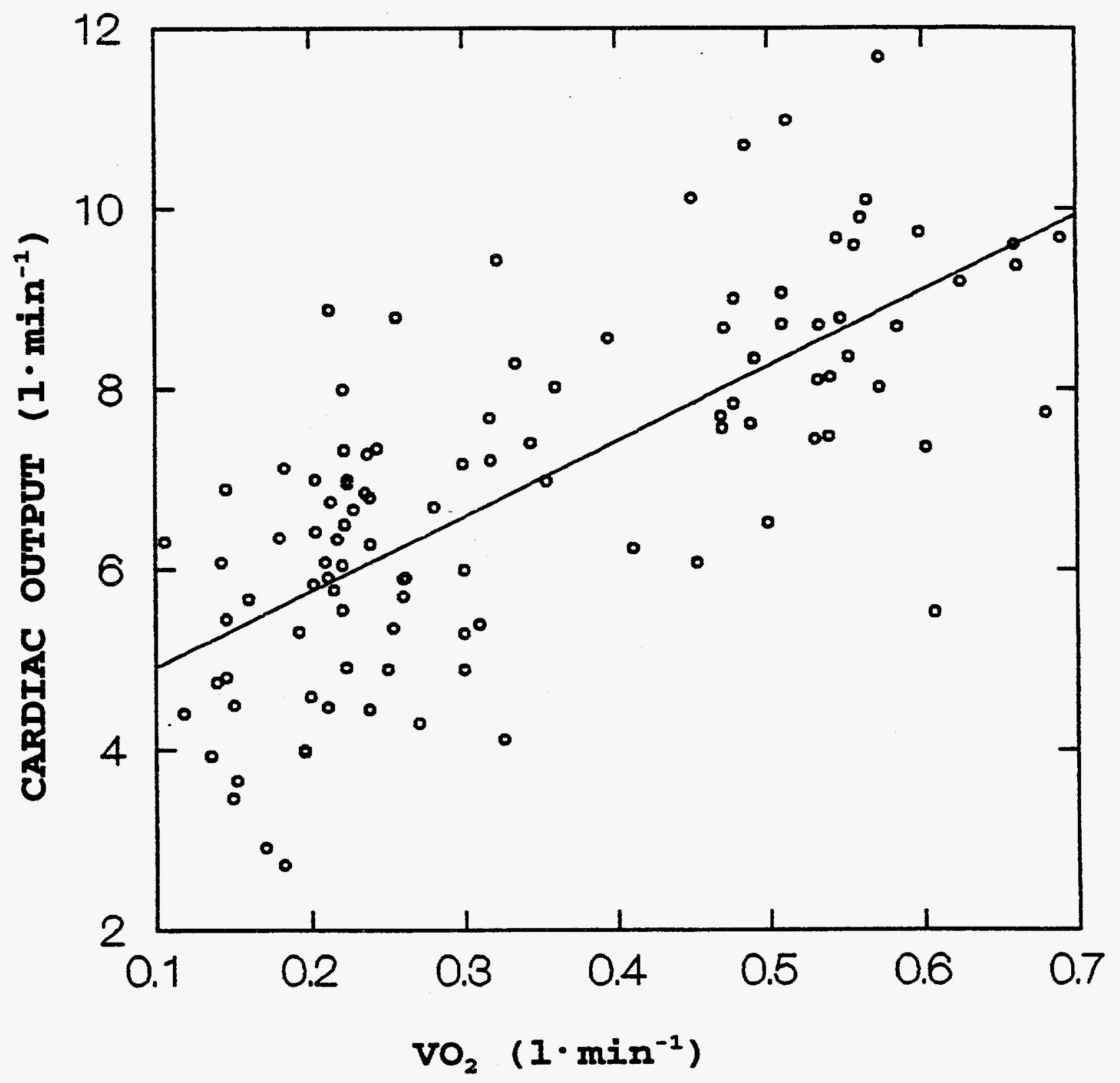


Figure 9. The regression line for cardiac output as a function of oxygen uptake is compared to individual values for males and females with $\mathrm{VO}_{2}$ values greater than $0.71 \cdot \mathrm{min}^{-1}$.

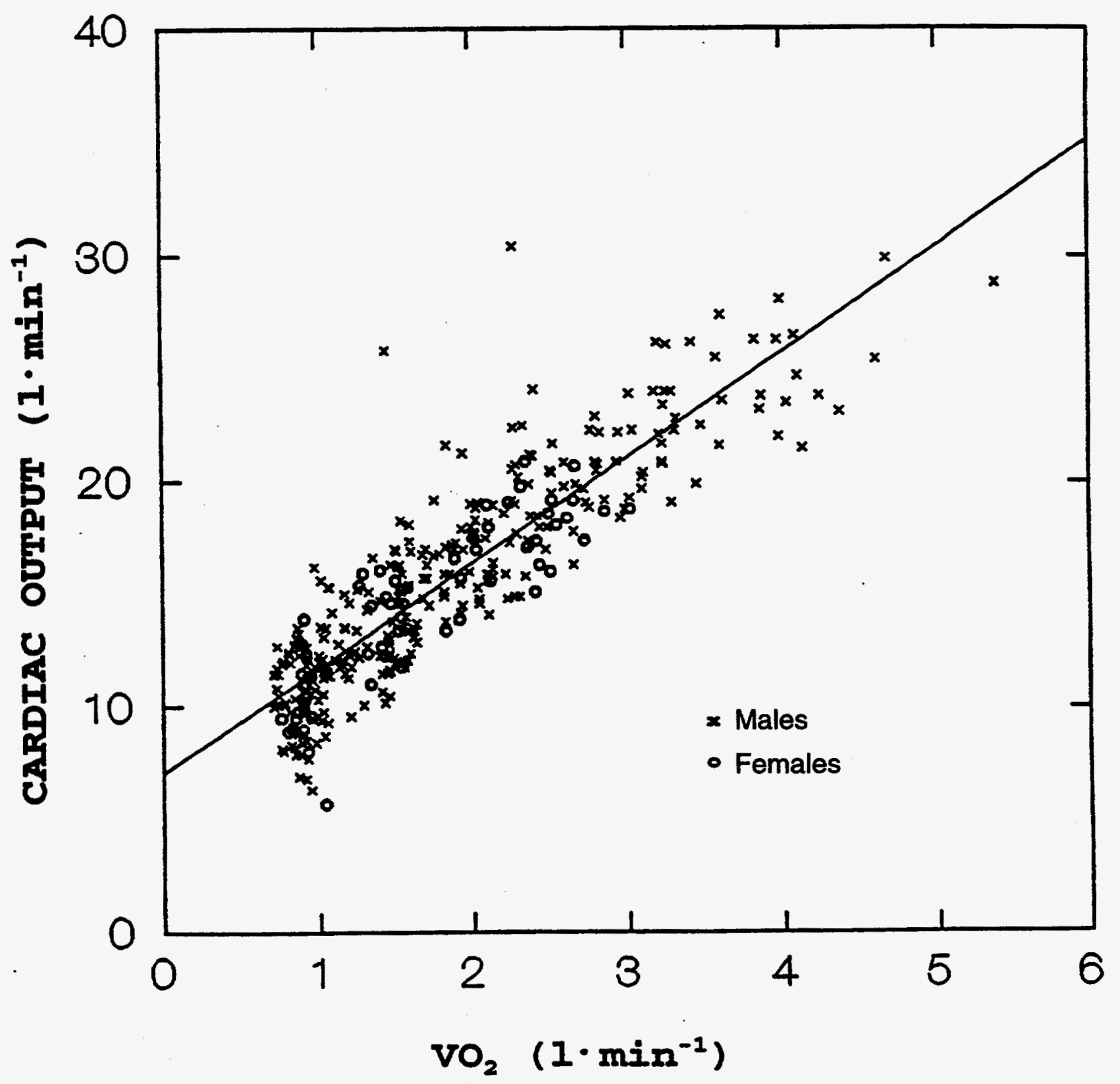


Figure 10. The regression line for cardiac index as a function of oxygen uptake is compared to individual values for males and females with $\mathrm{VO}_{2}$ values less than or equal to $0.7 \mathrm{l} \cdot \mathrm{min}^{-1}$.

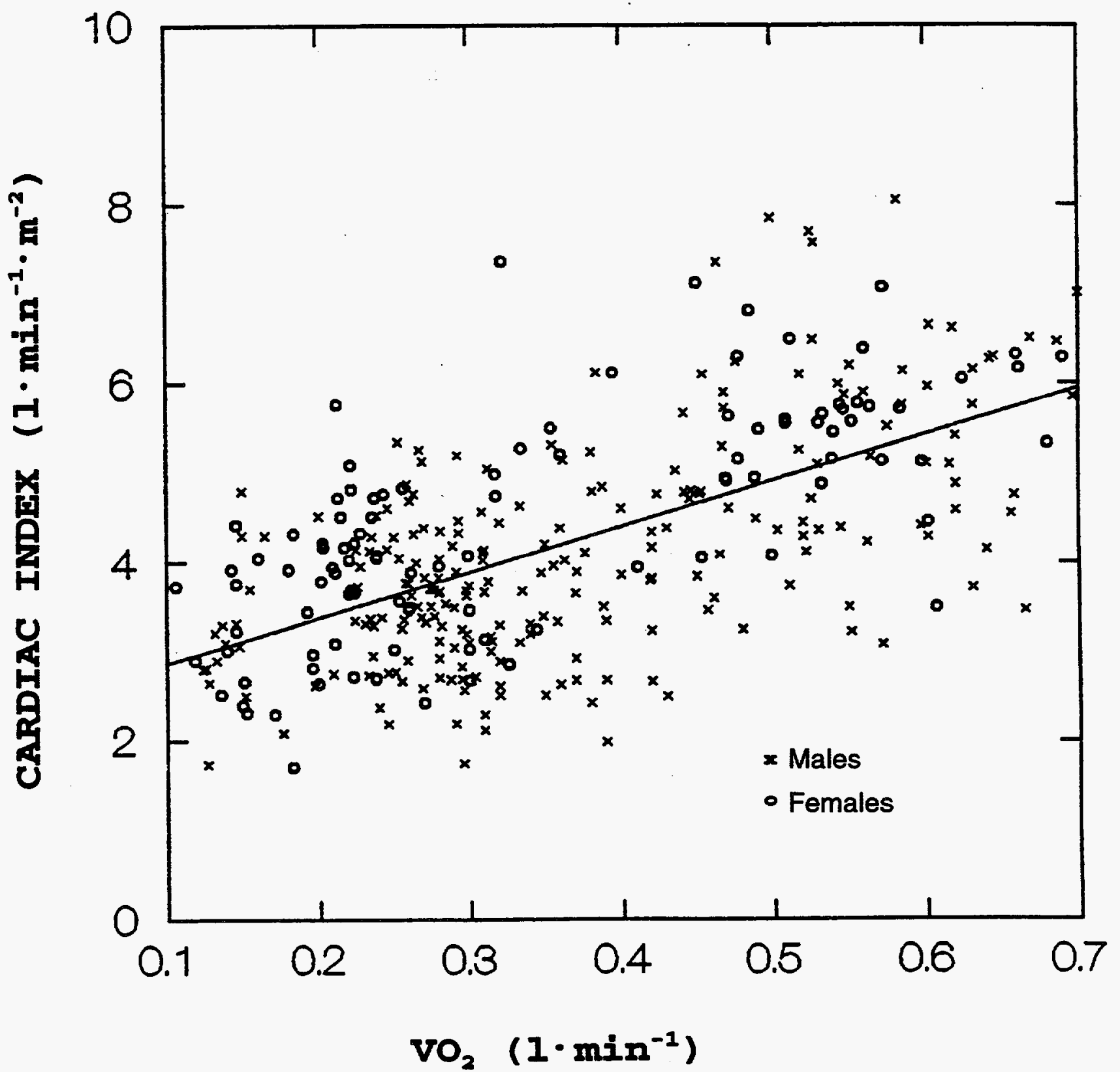


Figure 11. The regression line for cardiac index as a function of oxygen uptake is compared to individual values for males and females with $\mathrm{VO}_{2}$ values greater than $0.7 \mathrm{l} \cdot \mathrm{min}^{-1}$.

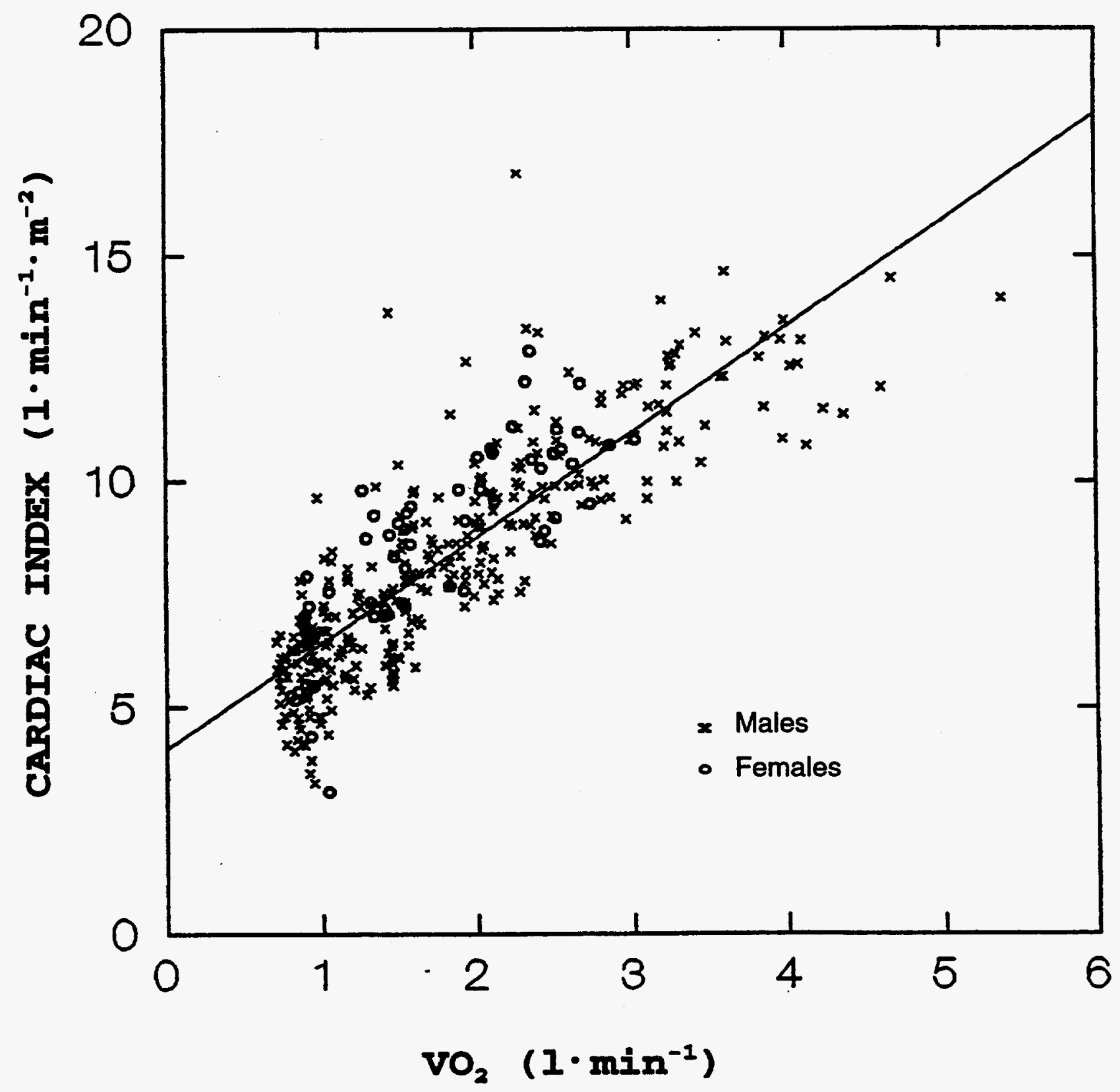




\section{F. Cardiac output during pregnancy}

Methods used to estimate $\mathrm{CO}$ before the introduction of the Cournand technique were inaccurate and tended to underestimate $\mathrm{CO}$, but some qualitative information can be obtained from the earlier results. In a summary of earlier studies, Hamilton (1949) reported an increase in CO during the first two trimesters of pregnancy that amounted to $45-85 \%$ of the non-pregnant level. Cardiac output reached a maximum by the 32nd week of pregnancy and there was a significant decrease in $\mathrm{CO}$ during the last four weeks of pregnancy. In studies using the Cournand technique, researchers (Adams 1954, Bader et al. 1955, Hamilton 1949, Rovinsky and Jaffin 1966, Roy et al. 1966, Ueland et al. 1969, Walters et al. 1966) reported comparable changes in supine CO during pregnancy.

The variation in basal $\mathrm{CO}$ among individuals makes it difficult to draw meaningful conclusions about changes in $\mathrm{CO}$ during pregnancy from studies that do not include serial measurements of subjects. Some studies (Adams 1954, Roy et al. 1966, Walters et al. 1966) contained serial measurements, but other researchers measured the $\mathrm{CO}$ of any particular individual at only one point during the pregnancy.

An additional problem occurs in studies that report supine $\mathrm{CO}$ but do not report $\mathrm{CO}$ in other body positions. It is now generally accepted that in the supine position there is a postural phenomenon that causes a significant decrease in $\mathrm{CO}$ during the last month of pregnancy due to a reduction in venous return following occlusion of the inferior vena cava by the uterus (Bieniarz et al. 1966). During the early stages of pregnancy, the decrease in $\mathrm{CO}$ in moving from supine to upright position is similar to the change observed in nonpregnant controls, but researchers (Lees et al. 1967, Pyorala 1966, Ueland et al. 1968, Ueland et al. 1973) report little difference in supine and upright $\mathrm{CO}$ during the latter stages of pregnancy. Also, with nonpregnant controls and during early stages of pregnancy there appears to be little difference between supine $\mathrm{CO}$ and lateral $\mathrm{CO}$, but researchers have found that lateral $\mathrm{CO}$ is greater than supine $\mathrm{CO}$ during the latter stages of pregnancy (reported averages range from 12\% to 34\%) (Campbell et al. 1985, Lees et al. 1967, Ueland et al. 1968, Ueland and Hansen 1969). The magnitude of the decrease in supine $\mathrm{CO}$ during the last trimester of pregnancy is approximately the same as the decrease in $\mathrm{CO}$ caused by moving from a lateral measurement to a supine measurement.

Results of studies on $\mathrm{CO}$ during pregnancy are insufficient for very precise statements about the change during and after pregnancy, but some general conclusions can be drawn. Supine CO returns to normal nonpregnant levels within 2-3 w postpartum (Adams 1954, Hamilton 1949). The 
increase in $\mathrm{CO}$ corresponding to a given increase in oxygen uptake during pregnancy is comparable to the nonpregnant response (Bader et al. 1955, Ueland et al. 1969). In any given body position, there appears to be a $15-25 \%$ increase in $\mathrm{CO}$ by the beginning of the second trimester, and by the 28 th to $32 \mathrm{nd}$ gestational week the maximum increase of $20-40 \%$ over the nonpregnant $\mathrm{CO}$ is achieved. Upright and laterally measured $\mathrm{CO}$ values do not decrease during pregnancy, but supine $\mathrm{CO}$ decreases during the last month of pregnancy to approximately the same level as the nonpregnant supine $\mathrm{CO}$. Although there is a slight increase in resting oxygen uptake as the pregnancy progresses, the increase in oxygen uptake is not enough to explain the increase in CO (Bader et al. 1955, Ueland et al. 1973).

A suggested reference curve for supine cardiac output during pregnancy is presented in Figure 12. Data from studies giving average $C O$ values at various stages of pregnancy are also plotted for comparison. Data from longitudinal studies are connected by dotted lines. Suggested reference curves for upright or lateral cardiac output during pregnancy would have approximately the same shape during the first two trimesters of pregnancy, but they would not decrease during the last trimester of pregnancy. 

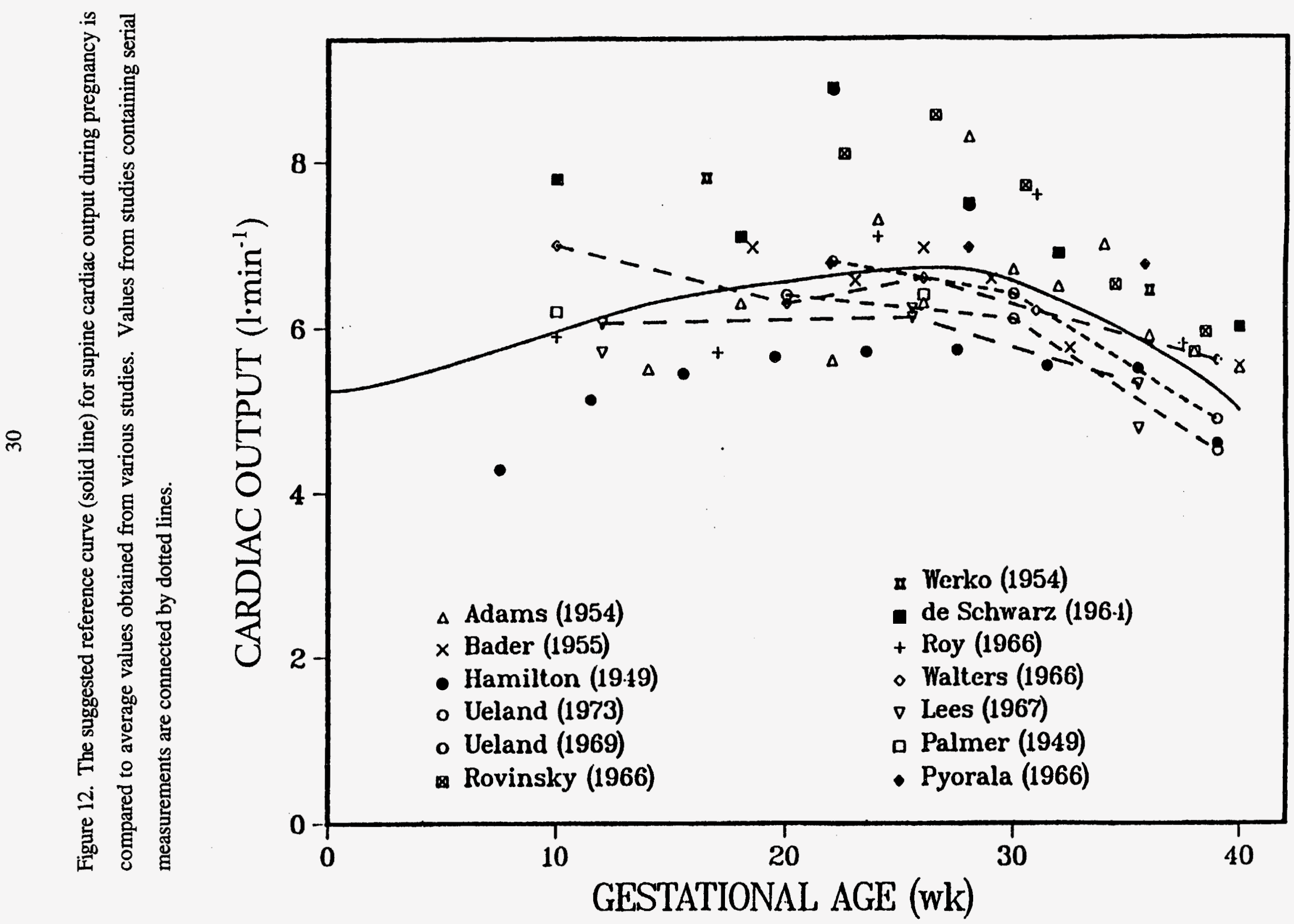


\section{SUMMARY}

Total blood volume for newborn infants can be reasonably estimated using a multiple of body weight, and TBV for children can be estimated using linear functions of weight and age for each sex. Reasonable estimates of TBV for adults can be obtained using linear expressions involving weight and height or weight and a power of height. The standard deviation in male or female TBV at a fixed age is $20-25 \%$ of the TBV value for children and approximately $15 \%$ of the TBV value for adults.

There does not appear to be a single method of standardization of $\mathrm{CO}$ with respect to a measure of body size that would give comparable distributions of values over all age ranges. Standardization with respect to BSA does not appear to explain a significant amount of the variation in adult $\mathrm{CO}$, but it does appear to remove the sex difference in the cardiac output distributions at a fixed age. For young and middle aged adult males and females, $\mathrm{CO}$ can be expressed as an increasing linear function of BSA and a decreasing linear function of age. The coefficient of variation

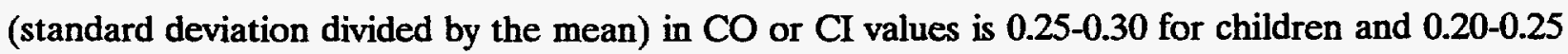
for adults in each sex group.

Resting $\mathrm{CO}$ appears to be at its maximum when the subject is lying horizontally. The resting seated $\mathrm{CO}$ is $15-20 \%$ less and the resting standing $\mathrm{CO}$ is $20-25 \%$ less than the $\mathrm{CO}$ value that is measured with the subject lying horizontally.

There is a significant correlation between $\mathrm{CO}$ and oxygen uptake in any fixed body position as the subject changes from a resting state to a state of light exercise. The slope of the relationship is near $\mathbf{8}$ for females and near $\mathbf{1 0}$ for males; each unit increase in oxygen uptake roughly corresponds to an 8-10 unit increase in $\mathrm{CO}$. The correlation between $\mathrm{CO}$ and oxygen uptake is even higher as the subject progresses from light exercise to moderately heavy exercise, but the slope of the relationship is much less. At higher work loads, each unit increase in oxygen uptake corresponds to approximately a 5 unit increase in $\mathrm{CO}$.

Resting CO of pregnant females measured with the subject upright or lying laterally increases throughout pregnancy with a possible leveling off during the latter stages of pregnancy. The resting pregnant $\mathrm{CO}$ may be $20-40 \%$ greater than the resting nonpregnant $\mathrm{CO}$ measured under the same conditions. Because of a reduction in venous return following occlusion of the inferior vena cava by the uterus, supine $\mathrm{CO}$ decreases toward the end of the pregnancy to values that approximate the nonpregnant supine $\mathrm{CO}$. 


\section{REFERENCES}

Adams FH, Lind J: Physiologic studies on the cardiovascular status of normal newborn infants (with special reference to the ductus arteriosus). Pediatrics 19:431-437, 1957.

Adams JQ: Cardiovascular physiology in normal pregnancy: Studies with the dye dilution technique. Am J Obst Gynec 67:741-759, 1954.

Allen TH, Pend MT, Chen KP, Huang TF, Chang C, Fang HS: Prediction of blood volume and adiposity in man from body weight and cube of height. Metab 5:328-345, 1956.

Anthonisen P, Crone C: Determination of cardiac output and pulmonary blood volume by means of indicator dilution technique. Dan Med Bull 6:43-49, 1959.

Astrand P, Cuddy TE, Saltin B, Stenberg J: Cardiac output during submaximal and maximal work. J Appl Physiol 19:268-274, 1964.

Bader RA, Bader ME, Rose DJ, Braunwald E: Hemodynamics at rest and during exercise in normal pregnancy as studied by cardiac catheterization. J Clin Invest 34:1524-1536, 1955.

Barratt-Boyes BG, Wood EH: Hemodynamic response of healthy subjects to exercise in the supine position while breathing oxygen. J Appl Physiol 11:129-135, 1957.

Barratt-Boyes BG, Wood EH: Cardiac output and related measurements and pressure values in the right heart and associated vessels, together with an analysis of the hemodynamic response to the inhalation of high oxygen mixtures in healthy subjects. J Lab Clin Med 51:72-90, 1958.

Berlin NI, Hyde GM, Parsons RJ, Lawrence JH, Port S: Blood volume of the normal female as determined with P32 labeled red blood cells. Proc Soc Exp Biol Med 76:831-832, 1951.

Bevegard S, Freyschuss U, Strandell T: Circulatory adaptation to arm and leg exercise in supine and sitting position. J Appl Physiol 21:37-46, 1966. 
Bickelmann AG, Lippschutz EJ, Weinstein L: The response of the normal and abnormal heart to exercise: A functional evaluation. Circ 28:238-250, 1963.

Bieniarz J, Maqueda E, Caldeyro-Barcia R: Compression of aorta by the uterus in late human pregnancy. I. Variations between femoral and brachial artery pressure with changes from hypertension to hypotension. Am J Obst Gynec 95:795-808, 1966.

Bing RJ, Maraist FM, Dammann JF, Draper A, Heimbecker R, Daley R, Gerard R, Calazel P: Effect of strophanthus on coronary blood flow and cardiac oxygen consumption of normal and failing human hearts. Circ 2:513-516, 1950.

Boer P, Roos JC, Geyskes GG, Dorhout Mess EJ: Measurement of cardiac output by impedance cardiography under various conditions. Am J Physiol 237:H491-H496, 1979.

Bolomey AA, Michie AJ, Michie C, Breed ES, Schreiner GE, Lauson HD: Simultaneous measurement of effective renal blood flow and cardiac output in resting normal subjects and patients with essential hypertension. J Clin Invest 28:10-17, 1949.

Brady LW, Cooper DY, Colodzin M, McClenathan JE, King ER, Williams R: Blood volume studies in normal humans. Surg Gynecol Obst 97:25-32, 1953.

Brandfonbrener M, Landowne M, Shock NW: Changes in cardiac output with age. Circ 12:557-566, 1955.

Bratteby L-E: Studies on erythro-kinetics in infancy. Acta Paediat Scand 57:132-136, 1968.

Brines JK, Gibson JG 2nd, Kunkel P: The blood volume in normal infants and children. J Pediatrics 18:447-457, 1941.

Brody S, Nilsson BA: Foetal and adult haemoglobin mass in relation to foetal development. J Obst Gynec Brit Comm 67:827-831, 1960. 
Brotmacher L, Fleming P: Cardiac output and vascular pressures in 10 normal children and adolescents. Guy's Hosp Rep 106:268-272, 1957.

Brown E, Hopper J Jr, Hodges JL Jr, Bradley B, Wennesland R, Yamauchi H: Red cell, plasma, and blood volumes in healthy women measured by radiochromium cell-labeling and hematocrit. J Clin Invest 41:2182-2190, 1962.

Campbell DM, Haites N, MacLennan F, Rawles J: Cardiac output in twin pregnancy. Acta Genet Med Gemellol 34:225-228, 1985.

Cayler GG, Rudolph AM, Nadas A S, Stone ME: Systemic blood flow in infants and children with and without heart disease. Pediatrics 32:186-201, 1963.

Chaplin H Jr., Mollison PL: Correction for plasma trapped in the red cell column of the hematocrit. Blood 7:1227-1238, 1952.

Chaplin H Jr., Mollison PL, Vetter H: The body/venous hematocrit ratio: Its constancy over a wide hematocrit range. J Clin Invest 32:1309-1316, 1953.

Chapman CB, Fraser RS: Studies on the effect of exercise on cardiovascular function. I. Cardiac output and mean circulation time. Circ 9:57-62, 1954a.

Chapman CB, Fraser RS: Studies on the effect of exercise on cardiovascular function. III. Cardiovascular response to exercise in patients with healed myocardial infarction. Circ 9:347-351, $1954 b$.

Chapman CB, Taylor HL, Borden C, Ebert RV, Keys A, Carlson WS: Simultaneous determinations of the resting arterio-venous oxygen difference by the acetylene and direct Fick methods. J Clin Invest 29:651-659, 1950.

Chien S, Usami S, Simmons RL, McAllister FF, Gregersen MI: Blood volume and age: repeated measurements on normal men after 17 years. J Appl Physiol 21:583-588, 1966. 
Cohn JE, Shock NW: Blood volume studies in middle-aged and elderly males. Am J Med Sci 217:388391, 1949.

Conway J: Clinical assessment of cardiac output. Eur Heart J 11:148-150, 1990.

Cournand A, Riley RL, Breed ES, Baldwin ED, Richards DW Jr, Lester MS, Jones M: Measurement of cardiac output in man using the technique of catheterization of the right auricle or ventricle. J Clin Invest 24:106-116, 1945.

Cropp GJA: Changes in blood and plasma volumes during growth. J Pediatrics 78:220-229, 1971.

de Leeuw PW, Birkenhagger WH: Some comments on the usefulness of measuring cardiac output by dye dilution. Eur Heart J 11:13-16, 1990.

Donald KW, Bishop JM, Cumming G, Wade OL: The effect of nursing positions on the cardiac output in man. Clin Sci 12:199-216, 1953.

Donald KW, Bishop JM, Cumming G, Wade OL: The effect of exercise on the cardiac output and circulatory dynamics of normal subjects. Clin Sci 14:37-73, 1955.

Donald KW, Wormald PN, Taylor SH, Bishop JM: Changes in the oxygen content of femoral venous blood and leg blood flow during leg exercise in relation to cardiac output response. Clin Sci 16:567$591,1957$.

Doyle JT, Wilson JS, Estes EH, Warren JV: The effect of intravenous infusions of physiologic saline solution on the pulmonary arterial and pulmonary capillary pressure in man. $J$ Clin Invest 30:345$352,1951$.

Ebert RV, Borden CW, Wells HS, Wilson RH: Studies of the pulmonary circulation. I. The circulation time from the pulmonary artery to the femoral artery and the quantity of blood in the lungs in normal individuals. J Clin Invest 28:1134-1137, 1949. 
Ekblom B, Astrand P, Saltin B, Stenberg J, Wallstrom B: Effect of training on circulatory response to exercise. J Appl Physiol 24:518-528, 1968.

Emmanouilides GC, Moss AJ, Monset-Couchard M, Marcano BA, Rzeznic B: Cardiac output in newborn infants. Biol Neonate 15:186-197, 1970.

Etsten BE, Li TH: The determination of cardiac output by the dye dilution method: Modifications, comparison with the Fick method, and application during anesthesia. Anesthesiology 15:217-220, 1954.

Etsten B, Li TH: Hemodynamic changes during thiopental anesthesia in humans: Cardiac output, stroke volume, total peripheral resistance, and intrathoracic blood volume. J Clin Invest 34:500-510, 1955.

Freedman ME, Snider GL, Brostoff P, Kimelblot S, Katz LN: Effects of training on response of cardiac output to muscular exercise in athletes. J Appl Physiol 8:37-47, 1955.

Fries ED, Schnaper HW, Johnson RL, Schreiner GE: Hemodynamic alterations in acute myocardial infarction. I. Cardiac output, mean arterial pressure, total peripheral resistance, "central" and total blood volumes, venous pressure and average circulation time. J Clin Invest 31:131-140, 1952.

Gehan EA, George SL: Estimation of human body surface area from height and weight. Cancer Chemother Rep 54:225-235,1970.

Gessner I, Krovetz L, Benson RW, Prystowsky H, Stenger V, Eitzman DV: Hemodynamic adaptations in the newborn infant. Pediatrics 36:752-762, 1965.

Gibson JG 2nd, Evans WA Jr: Clinical studies of the blood volume. II. The relation of plasma and total blood volume to venous pressure, blood velocity rate, physical measurements, age and sex in ninety normal humans. J Clin Invest 16:317-328, 1937. 
Gibson JG 2nd, Peacock WC, Seligman AM, Sack T: Circulating red cell volume measured simultaneously by the radioactive iron and dye methods. J Clin Invest 25:838-847, 1946.

Gilmore HR, Kopelman H, McMichael J, Milne IG: The effect of hexamethonium bromide on the cardiac output and pulmonary circulation. Lancet 263:898-902, 1952.

Granath A, Jonsson B, Strandell T: Studies on the central circulation at rest and during exercise in the supine and sitting body position in old men: Preliminary report. Acta Med Scand 169:125-126, 1961.

Granath A, Jonsson B, Strandell T: Circulation in healthy old men, studied by right heart catheterization at rest and during exercise in supine and sitting position. Acta Med Scand 176:425446, 1964.

Granath A, Strandell T: Relationships between cardiac output, stroke volume and intracardiac pressures at rest and during exercise in supine position and some anthropometric data in healthy old men. Acta Med Scand 176:447-466, 1964.

Grimby G, Nilsson NJ, Saltin B: Cardiac output during submaximal and maximal exercise in active middle-aged athletes. J Appl Physiol 21:1150-1156, 1966.

Guyton AC, Jones CE, Coleman TG: Circulatory Physiology: Cardiac Output and its Regulation. Philadelphia, WB Saunders, 1973, pp 3-20.

Hagan RD, Diaz FJ, Horvath SM: Plasma volume changes with movement to supine and standing positions. J Appl Physiol 45:414-418, 1978.

Hamilton HFH: The cardiac output in normal pregnancy as determined by the Cournand right heart catheterization technique. J Obst Gynaec Br Emp 56:548-552, 1949. 
Hamilton WF, Riley RL, Attyah AM, Cournand A, Powell DM, Himmelstein A, Noble RP, Remington JW, Richards DW Jr, Wheeler NC, Witham AC: Comparison of the Fick and dye injection methods of measuring the cardiac output in man. Am J Physiol 153:309-321, 1948.

Hanson JS, Tabakin BS, Levy AM, Hill DB: Comparative exercise-cardiorespiratory performance of normal men in the third, fourth, and fifth decades of life. Circ 37:345-360, 1968.

Hartley LH, Grimby G, Kilbom A, Nilsson NJ, Astrand I, Bjure J, Ekblom B, Saltin B: Physical training in sedentary middle-aged and older men. III. Cardiac output and gas exchange at submaximal and maximal exercise. Scand J Clin Lab Invest 24:335-344, 1969.

Holmgren A, Jonsson B, Sjostrand T: Circulatory data in normal subjects at rest and during exercise in recumbent position, with special reference to the stroke volume at different work intensities. Acta Physiol Scand 49:343-363, 1960.

Inkley SR, Brooks L, Krieger H: A study of methods for the prediction of plasma volume. J Lab Clin Med 45:841-850, 1955.

Jegier W, Sekelj P, Auld PAM, Simpson R, McGregor M: The relation between cardiac output and body size. Brit Heart J 25:425-430, 1963.

Julius S, Amery A, Whitlock LS, Conway J: Influence of age on the hemodynamic response to exercise. Circ 36:222-230, 1967.

Kadota LT: Theory and application of thermodilution cardiac output measurement: A review. Heart Lung 14:605-614, 1985.

Katori R: Normal cardiac output in relation to age and body size. Tohoku J Exp Med 128:377-387, 1979. 
Kattus AA, Rivin AU, Cohen A, Sofio GS: Cardiac output and central volume as determined by dye dilution curves: Resting values in normal subjects and patients with cardiovascular disease. Circ 11:447-455, 1955.

Kennedy JW, Baxley WA, Figley MM, Dodge HT, Blackmon JR: Quantitative angiocardiography. I. The normal left ventricle in man. Circ 34:272-278, 1966.

Klausen K: Cardiac output in man in rest and work during and after acclimatization to $3,800 \mathrm{~m}$. $\mathrm{J}$ Appl Physiol 21:609-616, 1966.

Kowalski HJ, Abelmann WH, McNeely WF, Frank NR, Ellis LB: The cardiac output of normal subjects determined by the dye-injection method at rest and during exercise. Am J Med Sci 228:622-625, 1954.

Krovetz LJ: The physiologic significance of body surface area. Med Prog 67:841-862, 1965.

Krovetz LJ, Goldbloom S: Normal standards for cardiovascular data. I. Examination of the validity of cardiac index. Johns Hopkins Med J 130:174-186, 1972.

Kuikka JT, Lansimies E: Effect of age on cardiac index, stroke index and left ventricular ejection fraction at rest and during exercise as studied by radiocardiography. Acta Physiol Scand 114:339$343,1982$.

Lammerant J, Veall N, De Visscher M: Observations on cardiac output and "pulmonary blood volume" in normal man by external recording of the intracardiac flow of ${ }^{131} \mathrm{I}$ labelled albumin. Nucl Med 1:353-379, 1961.

Lees MM, Taylor SH, Scott DB, Kerr MG: A study of cardiac output at rest throughout pregnancy. J Obst Gynaec Br Comm 74:319-328, 1967. 
Lehtovirta P, Kuikka J, Rekonen A, Pyorala T: Haemodynamic alterations produced by changes in posture with special reference to the usefulness of isotope ${ }^{113 m}$ In radiography. Ann Clin Res 4:285$295,1972$.

Levine HJ, Neill WA, Wagman RJ, Krasnow N, Gorlin R: The effect of exercise on mean left ventricular ejection rate in man. J Clin Invest 41:1050-1058, 1962.

Levinson GE, Pacifico AD, Frank MJ: Studies of cardiopulmonary blood volume: Measurement of total cardiopulmonary blood volume in normal human subjects at rest and during exercise. Circ 33:347-356, 1966.

Lucas RV Jr, St. Geme JW Jr, Anderson RC, Adams P Jr, Ferguson DJ: Maturation of the pulmonary vascular bed. Am J Dis Child 101:467-475, 1961.

Luisada AA, Bhat PK, Knighten V: Changes of cardiac output caused by aging: An impedance cardiographic study. Angiology 31:75-81, 1980.

McDonough JR, Danielson RA: Variability in cardiac output during exercise. J Appl Physiol 37:579$583,1974$.

McGregor M, Adam W, Sekelj P: Influence of posture on cardiac output and minute ventilation during exercise. Circ Res 9:1089-1092, 1961.

McMichael J, Sharpey-Schafer EP: Cardiac output in man by a direct Fick method: Effects of posture, venous pressure change, atropine, and adrenaline. $\mathrm{Br}$ Heart $\mathrm{J}$ 6:33-40, 1944.

Moore FD, Olesen KH, McMurrey JD, Parker HV, Ball MR, Boyden CM: The body cell mass and its supporting environment. First printing. Philadelphia: W. B. Saunders Company, 1963.

Morse M, Cassels DE, Schlutz RW: Blood volumes of normal children. Am J Physiol 151:448-458, 1947. 
Muiesan G, Sorbini CA, Solinas E, Grassi V, Casucci G, Peltz E: Comparison of $\mathrm{CO}_{2}$-rebreathing and direct Fick methods for determining cardiac output. J Appl Physiol 24:424-429, 1968.

Murata K, Yamane O, Suga H, Yamamoto S, Kogure S, Hojo Y, Baba N: Alterations of circulatory responses to upright tilt in cardiac patients. Jpn Heart J 44:551-560, 1981.

Myers JD: The hepatic blood flow and splanchnic oxygen consumption of man--their estimation from urea production or bromsulphalein excretion during catheterization of hepatic veins. J Clin Invest 26:1130-1137, 1947.

Nadler SB, Hidalgo JU: Blood volume. Edited by Sevelius G. London, JA Churchill, 1965, pp 65-93.

Nomof N, Hopper J Jr, Brown E, Scott K, Wennesland R: Simultaneous determination of the total volume of red blood cells by use of carbon monoxide and chromium in healthy and diseased human subjects. J Clin Invest 33:1382-1387, 1954.

Norryd C, Dencker H, Lunderquist A, Olin T: Superior mesenteric blood flow in man studied with a dye-dilution technique. Acta Chir Scand 141:109-118, 1974.

Nylin G, Hedlund S, Regnstrom O: Studies of the cerebral circulation with labeled erythrocytes in healthy man. Circ Res 9:664-674, 1961.

Ohisson J, Hastala MP, Tranesjo J, Wranne B: Non-invasive determination of effective stroke volume: Evaluation of a $\mathrm{CO}_{2}$-rebreathing method in normal subjects and patients. Clin Physiol 3:9$18,1983$.

Prec KJ, Cassels DE: Dye dilution curves and cardiac output in newborn infants. Circ 11:789-798, 1955.

Pyorala T: Cardiovascular response to the upright position during pregnancy. Acta Obst Gynec Scand 45(Suppl. 5):1-116, 1966. 
Rankin LS, Moos S, Grossman W: Alterations in preload and ejection phase indices of left ventricular performance. Circ 51:910-915, 1975.

Reeves JT, Grover RF, Blount SG Jr, Filley GF: Cardiac output response to standing and treadmill walking. J Appl Physiol 16:283-288, 1961a.

Reeves JT, Grover RF, Filley GF, Blount SG Jr: Circulatory changes in man during mild supine exercise. J Appl Physiol 16:279-282, 1961 b.

Regan TJ, Timmis G, Gray M, Binak K, Hellems HK: Myocardial oxygen consumption during exercise in fasting and lipemic subjects. J Clin Invest 40:624-630, 1961.

Retzlaff JA, Tauxe WN, Kiely JM, Stroebel CF: Erythrocyte volume, plasma volume, and lean body mass in adult men and women. Blood 33:649-667, 1969.

Riedinger MS, Shellock FG: Technical aspects of the thermodilution method for measuring cardiac output. Heart Lung 13:215-221, 1984.

Riley RL, Himmelstein A, Motley HL, Weiner HM, Cournand A: Studies of the pulmonary circulation at rest and during exercise in normal individuals and in patients with chronic pulmonary disease. Am J Physiol 152:372-382, 1948.

Ross J Jr, Gault JH, Mason DT, Linhart JW, Braunwald E: Left ventricular performance during muscular exercise in patients with and without cardiac dysfunction. Circ 34:597-608, 1966.

Rotta A, Canepa A, Hurtado A, Velasquez T, Chavez R: Pulmonary circulation at sea level and at high altitudes. J Appl Physiol 9:328-336, 1956.

Rovinsky JJ, Jaffin H: Cardiovascular hemodynamics in pregnancy. II. Cardiac output and left ventricular work in multiple pregnancy. Am J Obst Gynec 95:781-786, 1966. 
Roy S, Malkani PK, Virik R, Bhatia ML: Circulatory effects of pregnancy. Am J Obst Gynec 96:221$225,1966$.

Russell AE, Smith SA, West MJ, Aylward PE, McRitchie RJ, Hassam RM, Minson RB, Wing LMH, Chalmers JP: Automated non-invasive measurement of cardiac output by the carbon dioxide rebreathing method: comparisons with dye dilution and thermodilution. Br Heart J 63:195-199, 1990.

Schmidt LA III, Iob V, Flotte CT, Hodgson PE, McMath M: Blood volume changes in the aged. Surgery 40:938-944, 1956.

Schnabel TG, Eliasch H, Thomasson B, Werko L: The effect of experimentally induced hypervolemia on cardiac function in normal subjects and patients with mitral stenosis. J Clin Invest 38:117-137, 1959.

Segel N, Dougherty R, Sackner MA: Effects of tilting on pulmonary capillary blood flow in normal man. J Appl Physiol 35:244-249, 1973.

Shaver JA, Kroetz FW, Leonard JJ, Paley HW: The effect of steady-state increases in systemic arterial pressure on the duration of left ventricular ejection time. J Clin Invest 47:217-230, 1968.

Shepherd JT, Bowers D, Wood EH: Measurement of cardiac output in man by injection of dye at a constant rate into the right ventricle or pulmonary artery. J Appl Physiol 7:629-638, 1955.

Slonim NB, Ravin A, Balchum OJ, Dressler SH: The effect of mild exercise in the supine position on the pulmonary arterial pressure of five normal human subjects. J Clin Invest 33:1022-1030, 1954.

Smith JJ, Bush JE, Wiedmeier VT, Tristani FE: Application of impedance cardiography to study of postural stress. J Appl Physiol 29:133-137, 1970.

Sproul A, Simpson E: Stroke volume and related hemodynamic data in normal children. Pediatrics 33:912-918, 1964. 
Stead EA Jr, Warren JV, Merrill AJ, Brannon ES: The cardiac output in male subjects as measured by the technique of right atrial catheterization: Normal values with observations on the effect of anxiety and tilting. $J$ Clin Invest 24:326-331, 1945.

Stenberg J, Astrand P, Ekblom B, Royce J, Saltin B: Hemodynamic response to work with different muscle groups, sitting and supine. J Appl Physiol 22:61-70, 1967.

Strandell T: Total Haemoglobin, blood volume and haemoblobin concentration at rest and circulatory adaptation during exercise in relation to some anthropometric data in old men compared with young men. Acta Med Scand 176:219-231, 1964.

Tabakin BS, Hanson JS, Merriam TW Jr, Caldwell EJ: Hemodynamic response of normal men to graded treadmill exercise. J Appl Physiol 19:457-464, 1964.

Thomas HD, Gaos C, Reeves JT: Resting arteriovenous oxygen difference and exercise cardiac output. J Appl Physiol 17:922-926, 1962.

Thomasson B: Cardiac output in normal subjects under standard basal conditions: The repeatability of measurements by the Fick method. Scand J Clin Lab Invest 9:365-376, 1957.

Tuckman J, Shillingford J: Effect of different degrees of tilt on cardiac output, heart rate, and blood pressure in normal man. Br Heart J 28:32-39, 1966.

Ueland K, Gills RE, Hansen JM: Maternal cardiovascular dynamics. I. Cesarean section under subarachnoid block anesthesia. Am J Obst Gynecol 100:42-54, 1968.

Ueland K, Hansen JM: Maternal cardiovascular dynamics. II. Posture and uterine contractions. Am J Obst Gynecol 103:1-7, 1969.

Ueland K, Novy MJ, Metcalfe J: Cardiorespiratory responses to pregnancy and exercise in normal women and patients with heart disease. Am J Obst Gynecol 115:4-10, 1973. 
Ueland K, Novy MJ, Peterson EN, Metcalfe J: Maternal cardiovascular dynamics. IV. The influence of gestational age on the maternal cardiovascular response to posture and exercise. Am J Obst Gynecol 104:856-864, 1969.

von Porat BTD: Blood volume determinations with the Evans blue dye method. Acta Med Scand Suppl 256:1-108, 1951.

Walters WAW, MacGregor WG, Hills M: Cardiac output at rest during pregnancy and the puerperium. Clin Sci 30:1-11, 1966.

Wang Y, Marshall RJ, Shepherd JT: The effect of changes in posture and of graded exercise on stroke volume in man. J Clin Invest 39:1051-1061, 1960.

Weissler AM, Leonard JJ, Warren JV: Effects of posture and atropine on the cardiac output. J Clin Invest 36:1656-1662, 1957.

Wennesland R, Brown E, Hopper J Jr, Hodges JL Jr, Guttentag OE, Scott KG, Tucker IN, Bradley B: Red cell, plasma and blood volume in healthy men measured by radiochromium $\left(\mathrm{Cr}^{51}\right)$ cell tagging and hematocrit: Influence of age, somatotype and habits of physical activity on the variance after regression of volumes to height and weight combined. J Clin Invest 38:1065-1077, 1959.

Werko L, Lagerlof H, Bucht H, Wehle B, Holmgren A: Comparison of the Fick and Hamilton methods for the determination of cardiac output in man. Scand J Clin Lab Invest 1:109-113, 1949. 
ORNL/TM-12814

\section{INTERNAL DISTRIBUTION LIST}

1. ORNL Patent Office

2. Central Research Library

3. Document Reference Section

4-5. Laboratory Records

6. Laboratory Records-RC

\section{EXTERNAL DISTRIBUTION LIST}

7-8. OSTI, U.S. Department of Energy, P.O. Box 62, Oak Ridge, Tennessee 37831

9. Office of Assistant Manager of Energy Research and Development, DOE/ORO, P.O. Box 2001, Oak Ridge, Tennessee 37831-8600 